\title{
The Effect of HMGB1, a Damage-Associated Molecular Pattern Molecule, on Polymorphonuclear Neutrophil Migration Depends on Its Concentration
}

\author{
Florence Berthelot Lakhdar Fattoum Sarah Casulli Joël Gozlan \\ Vincent Maréchal Carole Elbim \\ Centre de Recherche des Cordeliers, Université Pierre et Marie Curie, UMR S 872 et Université Paris Descartes, \\ UMR S 872, INSERM, Paris, France
}

\section{Key Words}

Neutrophils $\cdot$ Alarmine $\cdot$ Chemotaxis $\cdot$ Inflammation

\begin{abstract}
Polymorphonuclear neutrophils (PMN) play a key role in host defenses against invading microorganisms but also potentiate inflammatory reactions in case of excessive or misdirected responses. Release of the alarmin high-mobility group box 1 (HMGB1) by cells that die at an inflammatory site may act as an alert signal for the immune system. We studied the effect of HMGB1 on human PMN migration, using wholeblood samples to avoid cell activation associated with isolation procedures. HMGB1 50-100 ng/ml reduced baseline PMN migration as well as formyl-methionyl-leucyl-phenylalanine- and IL-8-induced PMN chemotaxis. This inhibitory effect was mediated by the RAGE receptor. In contrast, a higher HMGB1 concentration $(5,000 \mathrm{ng} / \mathrm{ml})$ had a chemoattractant effect on PMN through IL-8 production. This effect required the engagement of Toll-like receptors 2 and 4 in addition to the RAGE receptor. The A box component of HMGB1, which antagonizes the endogenous protein, reduced chemotaxis and also strongly inhibited the enhancement of PMN migration observed with the highest HMGB1 concentration. In contrast, the $B$ box, reported to be the active form of HMGB1, exerted a chemoattractant effect. These results
\end{abstract}

strongly point to a key regulatory role of HMGB1 in PMN recruitment to inflammatory tissues. The A box component could potentially serve to inhibit inappropriate $\mathrm{PMN}$ recruitment during chronic inflammatory disorders associated with excessive HMGB1 release.

Copyright $\odot 2011$ S. Karger AG, Basel

\section{Introduction}

Polymorphonuclear neutrophils (PMN) are key components of the first line of defense against microbial pathogens, being rapidly recruited to inflammatory sites in response to a variety of stimuli. Once at their target site, PMN produce reactive oxygen species (ROS), which are essential for bacterial killing and also potentiate inflammatory reactions [1]. PMN are attracted by a variety of molecules, including formyl-methionyl-leucyl-phenylalanine (fMLP), a bacterial peptide, and chemokines such as IL-8, which are released from sites of inflammation or injury [2]. fMLP and IL-8 bind to receptors on PMN, resulting in both $\mathrm{G}$ protein-dependent and $\mathrm{G}$ protein-independent responses that induce PMN migration along a concentration gradient. This process is tightly controlled, not only to ensure efficient migration to inflammatory sites, but also to prevent aberrant tissue infiltration and

\section{KARGER \\ Fax +4161306 1234 \\ E-Mail karger@karger.ch}

www.karger.com (c) 2011 S. Karger AG, Basel

1662-811X/12/0041-0041\$38.00/0

Accessible online at:

www.karger.com/jin
Prof. Carole Elbim

Centre de Recherche des Cordeliers

Université Pierre et Marie Curie - Paris 6, UMR S 872

15 rue de l'École de Médecine, FR-75006 Paris (France)

Tel. +33 1442771 09, E-Mail carole.elbim@upmc.fr 
damage. Negative signals present at inflammatory sites prevent PMN recruitment, dampen PMN responsiveness and counterbalance or terminate the inflammatory response. This anti-inflammatory program is characterized by cessation of PMN infiltration.

High-mobility group box 1 (HMGB1) is a nuclear protein loosely bound to DNA, which stabilizes nucleosome formation and regulates transcription [3]. HMGB1 is found in all mammalian tissues and is highly conserved among species. HMGB1 consists of a single polypeptide chain of 215 amino acids organized into two DNA-binding regions (the $\mathrm{A}$ and $\mathrm{B}$ box) and a $\mathrm{C}$-terminal acidic tail. HMGB1 can be actively secreted into the extracellular space by activated macrophages, natural killer cells and mature dendritic cells, a process that may require HMGB1 acetylation in the nucleus. HMGB1 is passively released by necrotic but not apoptotic cells, and is thus a key signal of tissue damage. Extracellular HMGB1 may interact with Toll-like receptor (TLR) 2 and TLR4, and/or receptor for advanced glycation end products (RAGE). As a danger signal, HMGB1 would be expected to trigger inflammation, but recent reports indicate that pure recombinant HMGB1 has no pro-inflammatory activity and only acts as a chemoattractant and a mitogen. HMGB1 acquires pro-inflammatory activity after binding to proinflammatory mediators such as IL-1 $\beta$, LPS and ssDNA [4-6]. Structure-function studies have shown that the active cytokine domain of HMGB1 is located in the DNAbinding B box, whereas the A box competes with HMGB1 for binding sites on the surface of activated macrophages and attenuates the biological function of full-length HMGB1; thus, the recombinant A box specifically antagonizes HMGB1 $[3,7]$.

Although HMGB1 has been reported to stimulate the motility of various cell types such as fibroblasts, dendritic cells, macrophages, smooth muscle cells and tumor cells [for review, see 3], it is unclear whether this includes human PMN. Orlova et al. [8] recently reported that HMGB1 induces a RAGE-mediated increase in PMN migration. However, this latter study used PMN isolated from their blood environment by procedures which may differently modulate cell surface receptor expression and thereby alter cell responses [9].

The aim of the present study was to assess the effect of HMGB1 on PMN migration in whole-blood conditions in order to avoid artifactual activation related to isolation procedures and to more closely reproduce physiological conditions. We also analyzed the respective roles of the A and $\mathrm{B}$ box on chemotaxis, cytoskeleton rearrangement and PMN activation status. Finally, we examined the pos- sible involvement of RAGE, TLR2 and TLR4 in the modulation of PMN migration by HMGB1, and investigated relevant transduction pathways.

\section{Materials and Methods}

\section{Reagents}

The reagents and sources were as follows: fMLP and L- $\alpha$ lysophosphatidylcholine (Sigma-Aldrich); cycloheximide, SB203580, PD98059 and wortmannin (Calbiochem); recombinant human IL-8 and anti-RAGE monoclonal antibody (R\&D Systems); ultrapurified LPS from Escherichia coli serotype R515 (Invivogen); PEconjugated anti-CD11b antibody (Dakopatts); 7-aminoactinomycin D (7-AAD), allophycocyanin-conjugated (APC) anti-CD15 antibody, PE-conjugated anti-phosphorylated p38MAPK and ERK1/2 antibodies, purified anti-phospho Akt (S472/S473) antibody, purified anti-L-selectin antibody, and cytometric bead array (CBA) kit (BD Pharmingen); FITC goat anti-mouse antibody (Nordic Immunology); FITC goat anti-rabbit polyclonal antibodies (Cell Signaling Technology); anti-human TLR2 and TLR4 antibodies (eBiosciences); unlabeled phalloidin, Alexa Fluor 488-phalloidin and SYTO16 (Invitrogen); hydroethidine (HE) (Fluka, Buchs, Switzerland); Transwell plates (Corning Costar).

\section{Purification of Recombinant Human HMGB1 and HMGB1}

Domains $A$ and $B$

Recombinant human HMGB1, HMGB1 domain A (residues 1-87) and HMGB1 domain B (residues 85-180) were produced from Escherichia coli strain BL21(DE3) pLysS transformed with pEt15b-6His-HMGB1 full-length, pEt15b-6His-A Box and pEt15b-6His-B Box as previously described $[10,11]$. The expression vector encoded human HMGB1 protein, domain A and domain $\mathrm{B}$ fused to a polyhistidine tag at their $\mathrm{N}$ termini. (His) ${ }_{6}-\mathrm{fu}-$ sion proteins of full-length HMGB1 and of domains A and B were extracted in denaturing conditions, then renaturated and affinity-purified on Ni-NTA spin columns as recommended in the Qiagen instruction manual. Contaminating endotoxin was removed with Triton X-114 [10] and full-length HMGB1, domains A and B were tested for endotoxin contamination using the Limulus amebocyte assay. In order to rule out possible denaturation of HMGB1 during protein production, the activity of HMGB1 was assessed in terms of the capacity of HMGB1 to bind to hemicatenated DNA $[11,12]$ and to stimulate migration of $3 \mathrm{~T} 3$ mouse fibroblasts [13].

\section{Measurement of PMN Chemotactic Activity}

Chemotaxis was measured in Transwell plates (Corning Costar) containing 3- $\mu \mathrm{m}$ pore-size polyvinylpyrrolidone-free polycarbonate filters [14]. The lower well of each chamber received 600 $\mu \mathrm{l}$ of HMGB1 (1-5,000 ng/ml) or advanced glycation end products (AGEs) $(1-5,000 \mathrm{ng} / \mathrm{ml})$ diluted in PBS plus $1 \%$ human serum albumin. IL- 8 at $25 \mathrm{ng} / \mathrm{ml}$ and $\mathrm{fMLP}$ at $10^{-7} \mathrm{M}$ were used as positive chemoattractant controls. Spontaneous migration was measured with PBS plus $1 \%$ human serum. The upper well received $100 \mu \mathrm{l}$ of healthy donor whole blood diluted $1 / 10$ in PBS. The chambers were incubated for 1,3 or $5 \mathrm{~h}$ at $37^{\circ} \mathrm{C}$. Samples were stained with APC-anti-CD15 for $15 \mathrm{~min}$, and $450 \mu \mathrm{l}$ of lysis solution was then added. The total number of PMN added to the upper well and the number of PMN that migrated to the lower well were 
determined by flow cytometry using TruCount tubes (BD Biosciences). In some experiments, whole-blood samples were pretreated for 5-20 min with cycloheximide $(10 \mu \mathrm{g} / \mathrm{ml})$, blocking TLR2, TLR4 or RAGE antibodies $(10 \mu \mathrm{g} / \mathrm{ml})$, or kinase inhibitors at optimal concentrations previously determined in whole blood (wortmannin 2,500 nM; PD98059 $50 \mu \mathrm{M}$; SB203580 $25 \mu \mathrm{M}$ ) [15].

In order to evaluate the effect of HMGB1 on IL-8- and fMLPinduced migration, the lower wells were pretreated with HMGB1 at various concentrations for $30 \mathrm{~min}$ and then with IL-8 (25 ng/ $\mathrm{ml})$ or $\mathrm{fMLP}\left(10^{-7} \mathrm{M}\right)$ for $180 \mathrm{~min}$.

\section{Determination of Adhesion Molecule Expression at the PMN} Surface

Whole-blood samples $(1 \mathrm{ml})$ were incubated at $37^{\circ} \mathrm{C}$ with PBS, TNF- $\alpha(100 \mathrm{U} / \mathrm{ml}$, used as a positive control), A box (1-5,000 ng/ ml, HMGB1 equivalent) or B box (1-5,000 ng/ml, HMGB1 equivalent) for $1 \mathrm{~h}$. In order to evaluate the effect of A or B box on IL8- and fMLP-induced changes in adhesion molecule expression, the samples were pretreated with A or B box at various concentrations for $15 \mathrm{~min}$ and then with IL-8 $(25 \mathrm{ng} / \mathrm{ml})$ or fMLP $\left(10^{-7} \mathrm{M}\right)$ for 45 or $5 \mathrm{~min}$, respectively. Samples $(100 \mu \mathrm{l})$ were stained at $4^{\circ} \mathrm{C}$ for $30 \mathrm{~min}$ with PE-anti-human CD11b or purified anti-L-selectin antibodies. To study L-selectin expression, samples were then washed with ice-cold PBS and incubated at $4^{\circ} \mathrm{C}$ for $30 \mathrm{~min}$ with FITC-goat anti-mouse antibody. Erythrocytes were lysed with FACS lysing solution (BD Biosciences) and white blood cells were resuspended in $1 \%$ paraformaldehyde-PBS and analyzed by flow cytometry. Nonspecific antibody binding was determined on cells incubated with the same concentration of an irrelevant antibody of the same isotype.

\section{F-Actin Assay}

Whole-blood samples were either kept on ice or incubated PBS, A box (1-5,000 ng/ml, HMGB1 equivalent) or B box (1-5,000 $\mathrm{ng} / \mathrm{ml}, \mathrm{HMGB} 1$ equivalent) for $1 \mathrm{~h}$. In order to evaluate the effect of A or B box on IL-8- and fMLP-induced changes in actin polymerization, the samples were pretreated with A or B box for $1 \mathrm{~h}$, and then with PBS, fMLP $\left(10^{-7} \mathrm{~mol} / \mathrm{l}\right)$ or IL- $8(25 \mathrm{ng} / \mathrm{ml})$ for $2 \mathrm{~min}$ at $37^{\circ} \mathrm{C}$. Cells obtained after red cell lysis were fixed with $1 \%$ paraformaldehyde-PBS, and F-actin was measured by flow cytometry as previously described [16]. One hundred microliters of cell suspension was incubated for $30 \mathrm{~min}$ at $0^{\circ} \mathrm{C}$ in $100 \mu \mathrm{l}$ of $8 \%$ paraformaldehyde and $200 \mu \mathrm{l} / \mathrm{ml} \mathrm{L}-\alpha$ lysophosphatidyl-choline in PBS alone or supplemented with $1 \mathrm{mmol} / \mathrm{l}$ unlabeled phalloidin to measure nonspecific binding of Alexa Fluor 488-phalloidin. Alexa Fluor 488 -phallodin $(20 \mu \mathrm{M})$ was then added to the suspension and incubation was continued for $30 \mathrm{~min}$ at $0^{\circ} \mathrm{C}$. After one wash in PBS, the cells were resuspended in $1 \%$ paraformaldehydePBS.

\section{Measurement of PMN Oxidative Burst}

Superoxide anion $\mathrm{O}_{2}^{\overline{2}}$ production was measured with a flowcytometric assay derived from the HE oxidation technique [15]: whole-blood samples $(500 \mu \mathrm{l})$ were loaded for $15 \mathrm{~min}$ with $\mathrm{HE}$ $(1,500 \mathrm{ng} / \mathrm{ml})$ at $37^{\circ} \mathrm{C}$ and then incubated with PBS, TNF- $\alpha(100$ $\mathrm{U} / \mathrm{ml}$, used as a positive control), A box (1-5,000 ng/ml, HMGB1 equivalent) or B box (1-5,000 ng/ml, HMGB1 equivalent) for $1 \mathrm{~h}$; samples were then treated with PBS or $10^{-6} \mathrm{M}$ fMLP for $5 \mathrm{~min}$. Red cells were lysed as described above and white cells were resuspended in $1 \%$ paraformaldehyde-PBS.

\section{Measurement of PMN Apoptosis}

Apoptosis of PMN in whole blood was quantified by using SYTO16 [17] and a vital dye (7-AAD) [15]. Following initiation of the apoptosis cascade, cells loaded with SYTO16 exhibit a characteristic initial reduction in fluorescence signal intensity which precedes plasma membrane rupture. As cell death processes advance, a further loss of SYTO16 fluorescence coincides with the loss of plasma membrane integrity [17]. Samples were incubated in 24 -well tissue culture plates at $37^{\circ} \mathrm{C}$ with $5 \% \mathrm{CO}_{2}$ for 3 and $24 \mathrm{~h}$ with PBS or HMGB1 (1-5,000 ng/ml). Cycloheximide $(10 \mu \mathrm{g} / \mathrm{ml})$ and LPS $(10 \mathrm{ng} / \mathrm{ml})$ were used as pro- and antiapoptotic controls, respectively [15]. Samples $(100 \mu \mathrm{l})$ were then washed twice in PBS, incubated on ice with APC-anti-CD15 for $15 \mathrm{~min}$, and then with SYTO16 $(20 \mathrm{nM})$ for $15 \mathrm{~min}$. After dilution in PBS $(500 \mu \mathrm{l})$, the samples were incubated with 7-AAD at room temperature for $15 \mathrm{~min}$ and analyzed immediately by flow cytometry.

\section{Study of Intracellular Phospho-Akt, Phospho-p38MAPK and} Phospho-ERK1/2

After incubation of whole-blood samples with PBS, A box (1-5,000 ng/ml, HMGB1 equivalent) or B box (1-5,000 ng/ml, HMGB1 equivalent) for various times at $37^{\circ} \mathrm{C}$, leukocytes were permeabilized in $90 \%$ methanol as previously reported [15]. Cells were then stained with anti-Akt phosphospecific for $1 \mathrm{~h}$ at room temperature and washed once in PBS-2\% HSA. Samples were then incubated for 30 min with FITC-goat anti-rabbit antibody. Phospho-p38MAPK and phospho-ERK1/2 contents were studied by staining with PE-conjugated anti-phospho-p38MAPK and antiphospho-ERK1/2 antibodies. After one wash, leukocytes were resuspended in $1 \%$ paraformaldehyde-PBS and analyzed by flow cytometry.

\section{Cytokine Production by Blood Cells}

Whole-blood PMN were cultured for 1,3 and $24 \mathrm{~h}$ at $37^{\circ} \mathrm{C}$ with $5 \% \mathrm{CO}_{2}$ in 24-well tissue culture plates (Costar) in RPMI 1640 medium (Sigma-Aldrich). HMGB1 (1-5,000 ng/ml) was added to the culture medium. LPS $(20 \mathrm{ng} / \mathrm{ml})$ was used as a positive control. Supernatants were stored at $-70^{\circ} \mathrm{C}$ for no longer than 15 days before assay. IL- 8, IL- 6 , IL- $1 \beta$ and TNF- $\alpha$ were detected simultaneously in supernatants by using the human inflammatory cytokine CBA kit (BD Pharmingen). The CBA working range is 20$5,000 \mathrm{pg} / \mathrm{ml}$ for each cytokine.

\section{Flow Cytometry}

We used a BD Biosciences LSRII device (Immunocytometry Systems). PMN functions were analyzed with DIVA software. To measure apoptosis in whole blood, PMN were identified on the CD15/SSC dot plot, and $2 \times 10^{5}$ events were counted per sample. In other experiments, forward and side scatter were used to identify the PMN population and to gate out other cells and debris; $10^{4}$ events were counted per sample. Cytokine levels were analyzed with CBA software (BD Pharmingen).

\section{Statistical Analysis}

Data are reported as means \pm SEM. Comparisons were based on ANOVA and Tukey's post hoc test, using Prism 3.0 software (Graph Pad Software). 

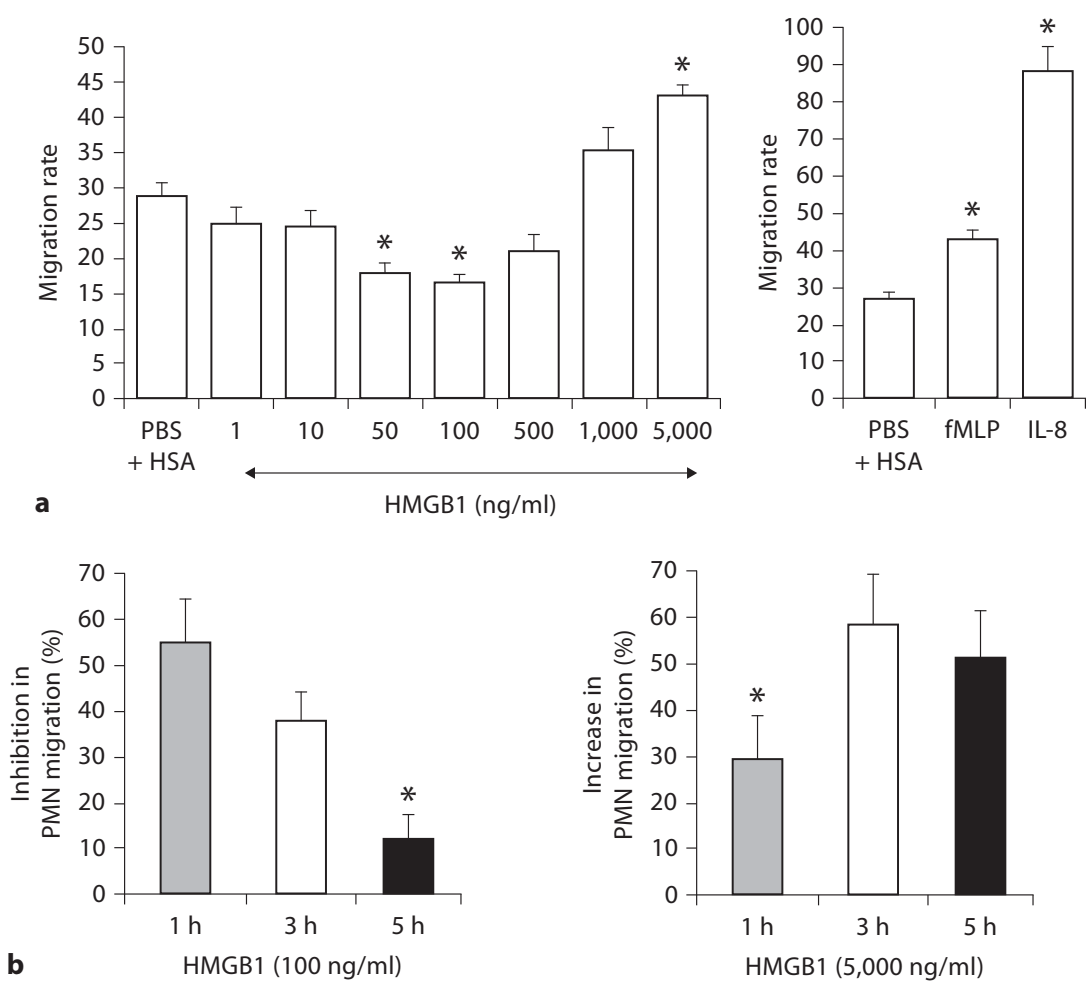

Fig. 1. HMGB1 has opposite effects on PMN migration according to the concentration. a Concentration-dependent effect of HMGB1 on PMN migration measured in Transwell plates. The lower well of each chamber received $600 \mu \mathrm{l}$ of PBS-HSA (1\%), and HMGB1 $(1-5,000 \mathrm{ng} / \mathrm{ml})$. IL-8 $(25 \mathrm{ng} / \mathrm{ml})$ and fMLP $\left(10^{-7} \mathrm{M}\right)$ were used as positive chemoattractant controls. The chambers were incubated for $3 \mathrm{~h}$ at $37^{\circ} \mathrm{C}$. The results are expressed as the migration rate (number of PMN in the lower well after migration/number of $\mathrm{PMN}$ applied to the upper well) $\times 100$. Values are means \pm SEM ( $\mathrm{n}=10$, each experiment performed in triplicate). ${ }^{*}$ Significantly different from PBS-HSA $(p<0.05)$. b Kinetic effect of HMGB1 on

\section{Results}

\section{HMGB1 Effects on PMN Migration Depend on the} Concentration

We first investigated the effect of HMGB1 (1-5,000 ng/ $\mathrm{ml}$ ) alone on migration of whole-blood PMN incubated for $3 \mathrm{~h}$ in Transwell plates. Maximal concentrations of IL-8 (25 $\mathrm{ng} / \mathrm{ml})$ and fMLP $\left(10^{-7} \mathrm{M}\right)$, used as positive controls, induced significant migration of PMN as compared to PBSHSA (fig. 1a). The highest concentration of HMGB1 (5,000 $\mathrm{ng} / \mathrm{ml}$ ) increased PMN migration to a similar extent to fMLP. Surprisingly, HMGB1 at lower concentrations (50 and $100 \mathrm{ng} / \mathrm{ml}$ ) significantly decreased baseline PMN mi-
PMN migration. The lower well of each chamber received $600 \mu \mathrm{l}$ of PBS-HSA, HMGB1 (100 ng/ml) or HMGB1 $(5,000 \mathrm{ng} / \mathrm{ml})$. The chambers were incubated for 1,3 or $5 \mathrm{~h}$ at $37^{\circ} \mathrm{C}$. The results are expressed as the percentage inhibition of PMN migration by HMGB1 $100 \mathrm{ng} / \mathrm{ml}$ [1 - (migration rate in HMGB1-treated sample/migration rate in PBS-HSA-treated sample) $] \times 100$ or the percentage increase in PMN migration with HMGB1 5,000 ng/ml [(migration rate in HMGB1-treated sample/migration rate in PBS-HSA-treated sample) -1$] \times 100$. Values are means \pm SEM $\left(\mathrm{n}=5\right.$, each experiment performed in triplicate). ${ }^{*}$ Significantly different from sample incubated with HMGB1 for $3 \mathrm{~h}(\mathrm{p}<0.05)$. 
Fig. 1. HMGB1 has opposite effects on PMN migration according to the concentration. c, d Effect of HMGB1 on chemoattractant-induced PMN migration. The lower wells of Transwell plates were pretreated with PBS-HSA (1\%) or HMGB1 at various concentrations $(1-5,000 \mathrm{ng} / \mathrm{ml})$ for $30 \mathrm{~min}$ and then with fMLP $\left(10^{-7} \mathrm{M}\right)$ or IL-8 $(25 \mathrm{ng} / \mathrm{ml})$ for $180 \mathrm{~min}$ at $37^{\circ} \mathrm{C}$. The results are expressed as the migration rate. Values are means $\pm \operatorname{SEM}(\mathrm{n}=5$, each experiment performed in triplicate). ${ }^{*}$ Significantly different from sample incubated with fMLP or IL-8 alone ( $p<0.05)$.

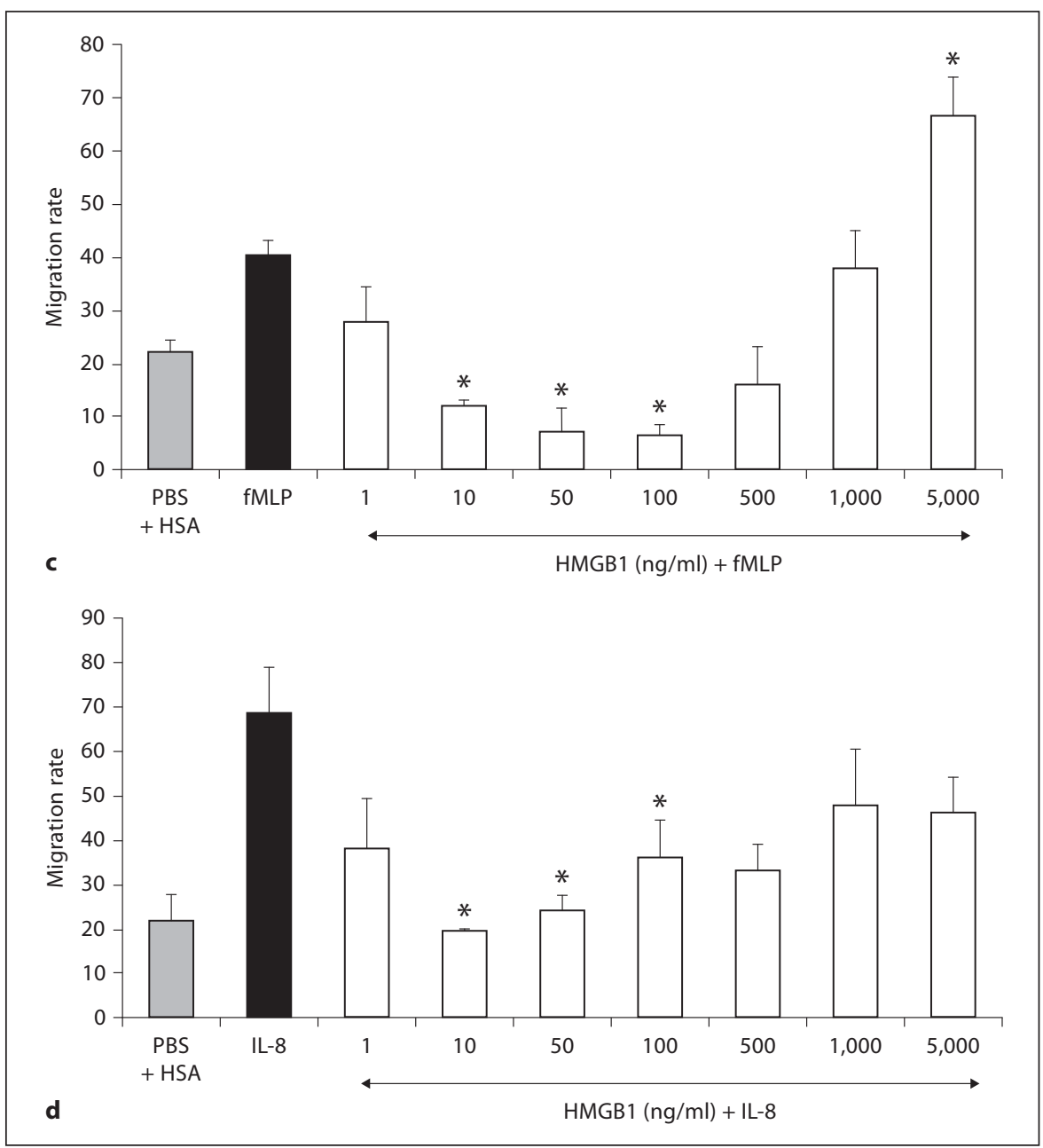

PMN, purified as previously reported [15]. HMGB1induced modulations of PMN migration were similar whether migration was studied in whole blood or in purified preparations, suggesting a direct effect of HMGB1 on PMN migration. However, the effects were slightly lower with purified PMN than with whole-blood $\mathrm{PMN}$ : in purified preparations, HMGB1 (100 $\mathrm{ng} / \mathrm{ml})$ induced $32-38 \%$ inhibition of PMN migration and the highest HMGB1 concentration induced a $15-21 \%$ increase in PMN migration. To minimize cell activation due to isolation procedures and to better mimic physiological conditions, subsequent experiments were performed with PMN in their whole-blood environment.

\section{HMGB1 Modulation of PMN Migration Is Not}

Related to Altered PMN Viability

Bloodstream PMN have a short half-life, dying physiologically by apoptosis. Apoptotic PMN are nonfunc- tional. We therefore investigated whether the observed changes in PMN migration were due to modulation of PMN survival. Whole-blood PMN cultured at $37^{\circ} \mathrm{C}$ died rapidly by apoptosis: about 10 and $70 \%$ of cells were SYTO ${ }^{\text {low+bright }}$ after 3 and $24 \mathrm{~h}$, respectively. As previously reported [15], apoptosis was accelerated by cycloheximide $\left(10 \mu \mathrm{g} / \mathrm{ml}: 18 \%\right.$ of cells were SYTO ${ }^{\text {low+bright }}$ after $3 \mathrm{~h}$ ) and delayed by LPS (10 $\mathrm{ng} / \mathrm{ml}: 4 \%$ of cells were SYTO $^{\text {low+bright }}$ after $3 \mathrm{~h}$ ) (fig. 2c). The percentage of apoptotic cells in samples incubated with HMGB1 (1-5,000 $\mathrm{ng} / \mathrm{ml}$ ) for $3 \mathrm{~h}$ was not different from the PBS control (fig. 2c). Similar results were obtained after $24 \mathrm{~h}$ (data not shown).

\section{HMGB1 A and B Box Have Opposite Effects on PMN Migration}

We then investigated the involvement of the A and $\mathrm{B}$ domains in HMGB1 modulation of PMN migration. The 

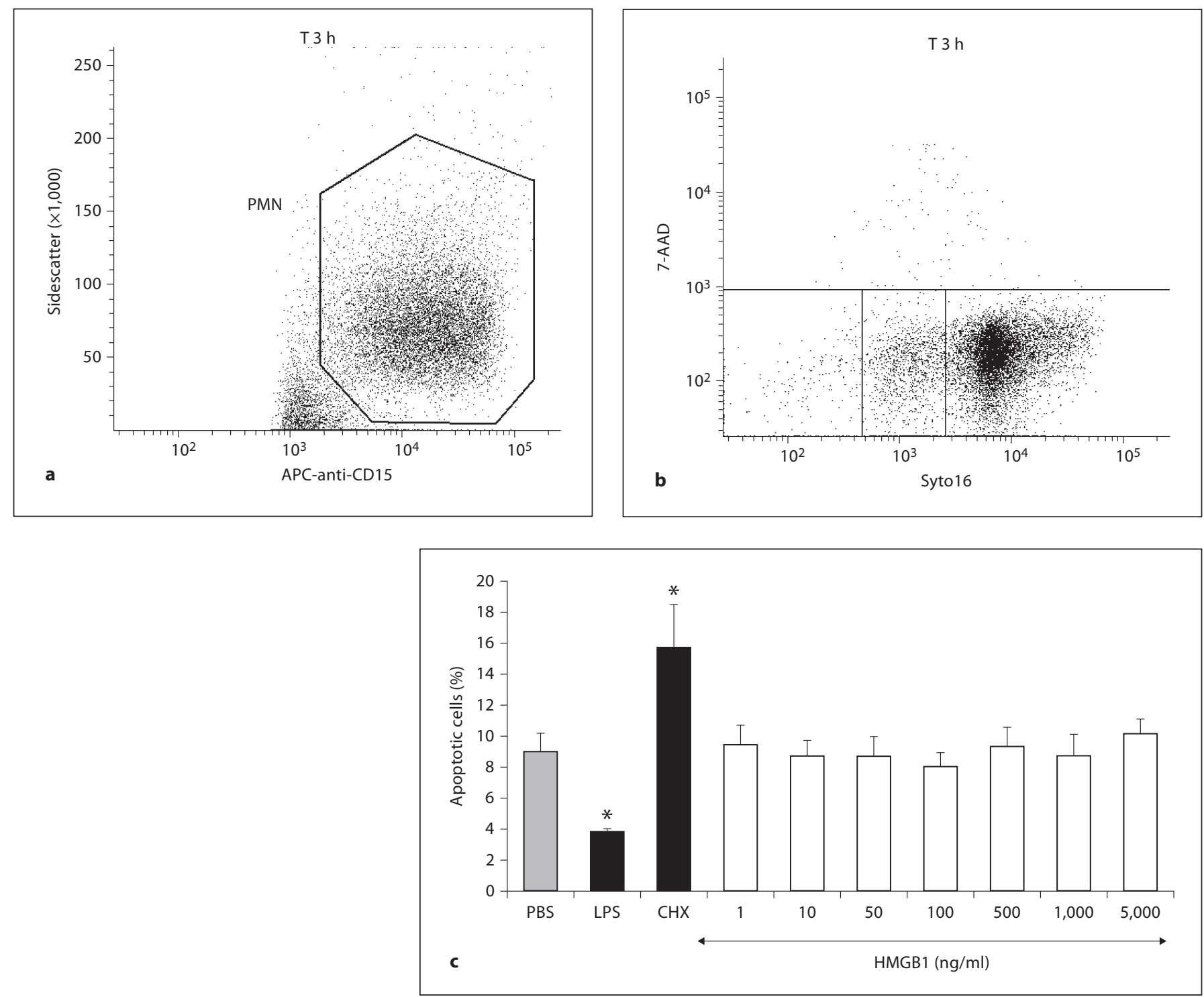

Fig. 2. HMGB1 does not modulate PMN viability. Whole-blood samples were incubated in 24 -well tissue culture plates at $37^{\circ} \mathrm{C}$ with $5 \% \mathrm{CO}_{2}$ for $3 \mathrm{~h}$ with PBS or HMGB1 (1-5,000 ng/ml). Cycloheximide $(10 \mu \mathrm{g} / \mathrm{ml})$ and LPS $(10 \mathrm{ng} / \mathrm{ml})$ were used as proapoptotic and antiapoptotic controls, respectively. Samples were then incubated at $4^{\circ} \mathrm{C}$ for 15 min with APC-anti-CD15 and stained with SYTO16 and 7-AAD as described in Materials and Methods. The fluorescence of anti-CD15 antibody was used to identify

A box (50-1,000 ng/ml HMGB1 equivalent) significantly decreased PMN random migration (fig. 3a) as well as fMLP- and IL-8-induced chemotaxis (fig. 3c, d). In addition, pretreatment of whole-blood samples with the A box (100 ng/ml HMGB1 equivalent) strongly accentuated the inhibition of PMN migration observed with $100 \mathrm{ng} / \mathrm{ml}$
PMN as CD15+ cells and to gate out other cells, erythrocytes, and debris. A gate was drawn around the PMN population (a) and fluorescence was analyzed in this gate. The combination of SYTO16 and 7-AAD distinguished among early apoptotic cells (SYTO $\left.{ }^{\text {bright }} / 7-\mathrm{AAD}-\right)$, late apoptotic cells (SYTO ${ }^{\text {low }} / 7-\mathrm{AAD}-$ ), necrotic cells (7-AAD+) and viable cells (SYTO $\left.{ }^{\text {high }} / 7-\mathrm{AAD}-\right)(\mathbf{b})$. The results are expressed as the percentage of total apoptotic cells (c). Values are means $\pm \operatorname{SEM}(\mathrm{n}=3)$. 


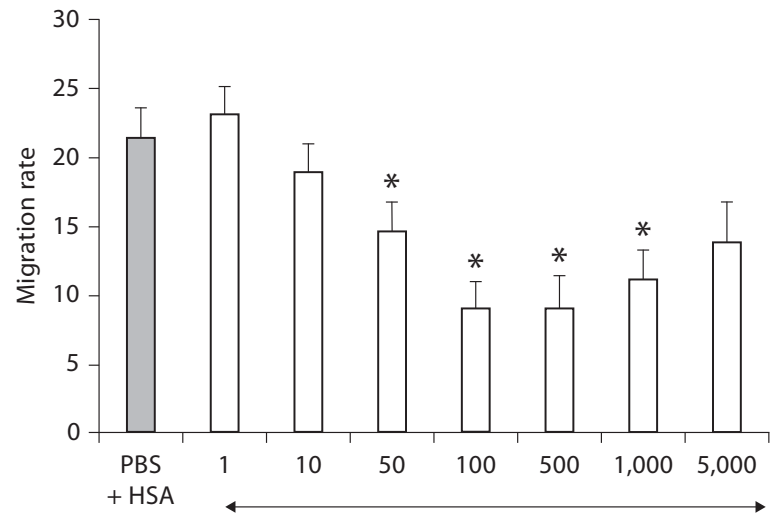

a

A box (ng/ml, eq HMGB-1)
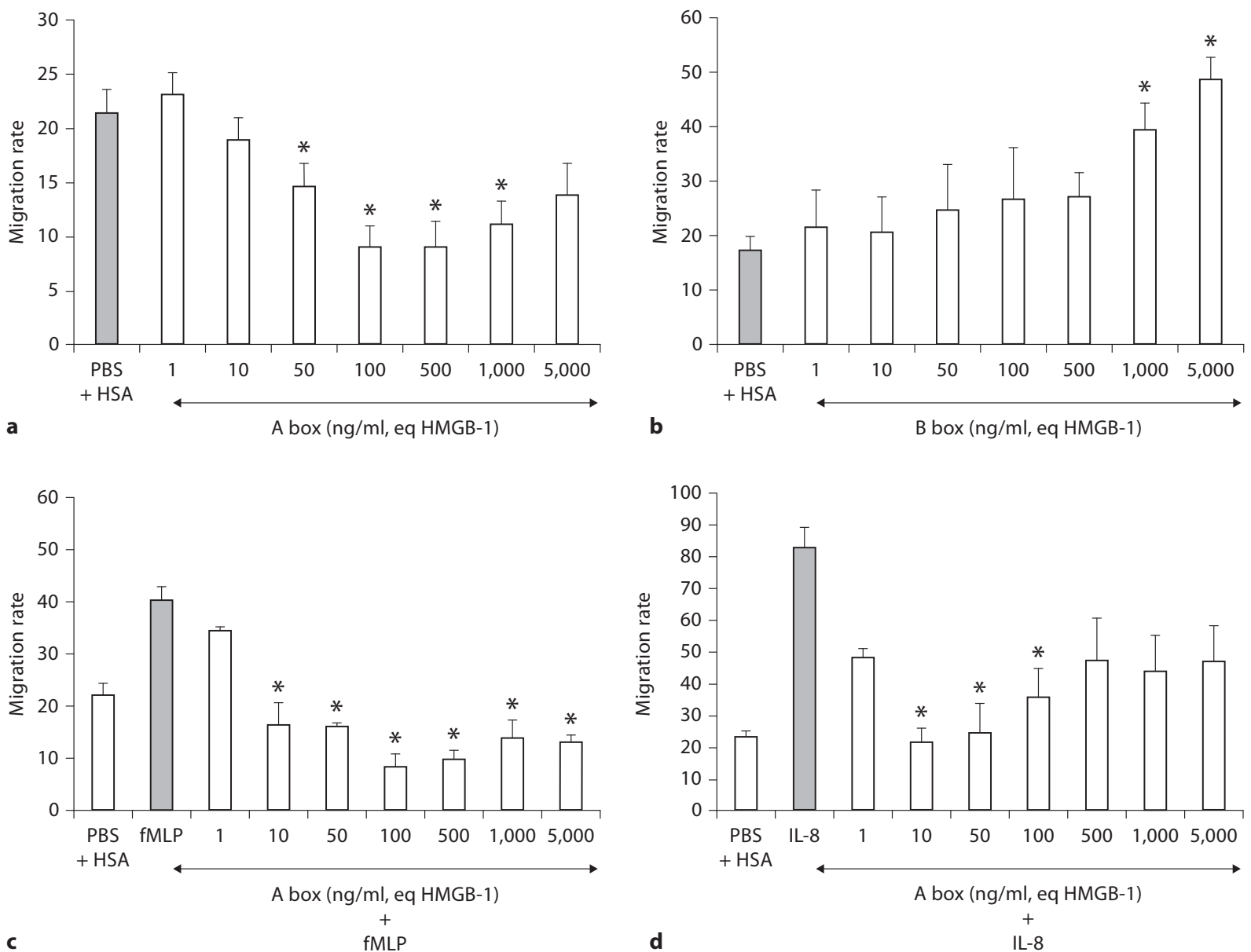

Fig. 3. Differential effects of A and B box on PMN migration. a, b A and B box had opposite effects on PMN migration. The lower well of each chamber received $600 \mu$ l of PBS-HSA, A box (1-5,000 ng/ml, HMGB1 equivalent) (a) or B box (1-5,000 ng/ml, HMGB1 equivalent) (b). The chambers were incubated for $1 \mathrm{~h}$ at $37^{\circ} \mathrm{C}$. The results are expressed as the migration rate calculated as described above. Values are means \pm SEM $(n=3$, each experiment performed in triplicate). c, $\mathbf{d}$ A box decreased chemoattrac-

Together, these data suggested that the B and A box might play key roles in the observed enhancement and inhibition, respectively, of PMN migration by HMGB1.

\section{HMGB1 A and B Box Modulations of PMN Migration}

Are Associated with Changes in F-Actin Content

F-actin is important for the cytoskeleton rearrangements necessary to induce a migratory phenotype in PMN [18]. We therefore investigated whether the differential effects of the two parts of HMGB1 on PMN migra-

tant-induced PMN migration. The lower wells were pretreated with PBS-HSA (1\%) or A box (1-5,000 ng/ml, HMGB1 equivalent) for $30 \mathrm{~min}$ and then with fMLP $\left(10^{-7} \mathrm{M}\right)(\mathbf{c})$ or IL-8 $(25 \mathrm{ng} / \mathrm{ml})(\mathbf{d})$ for $1 \mathrm{~h}$ in Transwell plates at $37^{\circ} \mathrm{C}$. The results are expressed as the migration rate calculated as described above. Values are means $\pm \operatorname{SEM}(\mathrm{n}=3$, each experiment performed in triplicate). * Significantly different from sample incubated with PBS-HSA (a, b, g, h), fMLP (c, e) or IL-8 (d, f) $(\mathrm{p}<0.05)$.

tion were associated with parallel changes in F-actin content. As shown in figure 4, treatment of whole-blood samples with A box reduced actin polymerization in unstimulated PMN (fig. 4a), as well as in response to fMLP (fig. 4c) and IL-8 (fig. 4d). In contrast, high B box concentrations (1,000 and 5,000 ng/ml HMGB1 equivalent) significantly increased the PMN F-actin content (fig. 4b). In addition, as observed above for PMN migration, HMGB1 $B$ box $(5,000 \mathrm{ng} / \mathrm{ml})$ and $\mathrm{FMLP}$ had a synergistic effect on F-actin content (fig. 4e). 


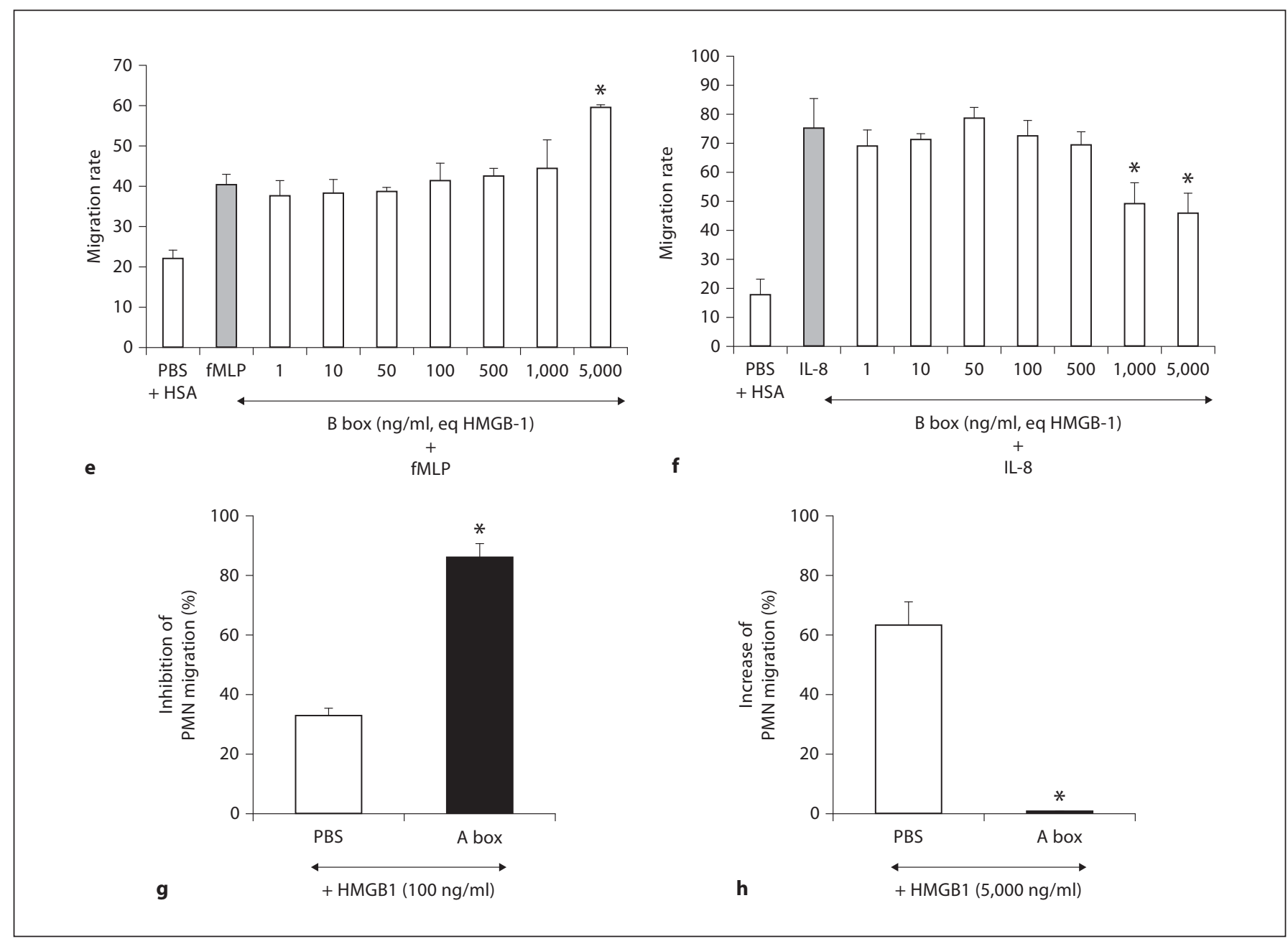

Fig. 3. Differential effects of A and B box on PMN migration. e, $\mathbf{f}$ Effect of B box on chemoattractant-induced PMN migration. The lower wells were pretreated with PBS-HSA (1\%) or B box (1$5,000 \mathrm{ng} / \mathrm{ml}, \mathrm{HMGB} 1$ equivalent) for $1 \mathrm{~h}$ and then with fMLP $\left(10^{-7} \mathrm{M}\right)(\mathbf{e})$ or IL-8 $(25 \mathrm{ng} / \mathrm{ml})(\mathbf{f})$ for $30 \mathrm{~min}$ in Transwell plates at $37^{\circ} \mathrm{C}$. The results are expressed as the migration rate calculated as described above. Values are means $\pm \operatorname{SEM}(n=3$, each experiment performed in triplicate). $\mathbf{g}, \mathbf{h}$ A box modulates HMGB1-induced changes in PMN migration. Before being applied to the upper chambers, whole-blood samples were pretreated at room temperature for $30 \mathrm{~min}$ with A box $(100 \mathrm{ng} / \mathrm{ml}$, HMGB1 equiva-

\section{Effect of HMGB1 A and B Box on PMN Adhesion Molecule Expression and Oxidative Burst}

As HMGB1 A and B box were found to modulate PMN migration, we then explored whether these two parts could also differentially affect neutrophil activation status in terms of adhesion molecule expression and ROS production. In keeping with the known role of CD11b during PMN migration [19], we found that the A box sig- lent). The lower well of each chamber received $600 \mu$ l of PBS-HSA or HMGB1 $(100 \mathrm{ng} / \mathrm{ml}$ or $5,000 \mathrm{ng} / \mathrm{ml})$ and the chambers were incubated at $37^{\circ} \mathrm{C}$ for $1 \mathrm{~h}$ (HMGB1 $\left.100 \mathrm{ng} / \mathrm{ml}\right)(\mathbf{g})$ or $3 \mathrm{~h}$ (HMGB1 $5,000 \mathrm{ng} / \mathrm{ml})(\mathbf{h})$. The results are expressed as the percentage inhibition or percentage increase, according to the HMGB1 concentration $(100 \mathrm{ng} / \mathrm{ml}$ or $5,000 \mathrm{ng} / \mathrm{ml}$, respectively) as described in the legend of fig. $1 \mathrm{~b}$. Values are means $\pm \operatorname{SEM}(\mathrm{n}=3$, each experiment performed in triplicate). ${ }^{*}$ Significantly different from sample incubated with PBS-HSA (a, b, g, h), fMLP (c, e) or IL-8 $(\mathbf{d}, \mathbf{f})(\mathrm{p}<0.05)$.

nificantly decreased CD11b expression as compared to the PBS control (fig. 5a) and counteracted chemoattractant-induced CD11b upregulation (fig. 5e, f). In contrast, the A box did not modify L-selectin expression (fig. 5c) and did not reverse L-selectin shedding after PMN activation by fMLP or IL-8 (data not shown). High B box concentrations induced an increase in CD11b expression and a decrease in L-selectin expression (fig. 5b, d). These mod- 


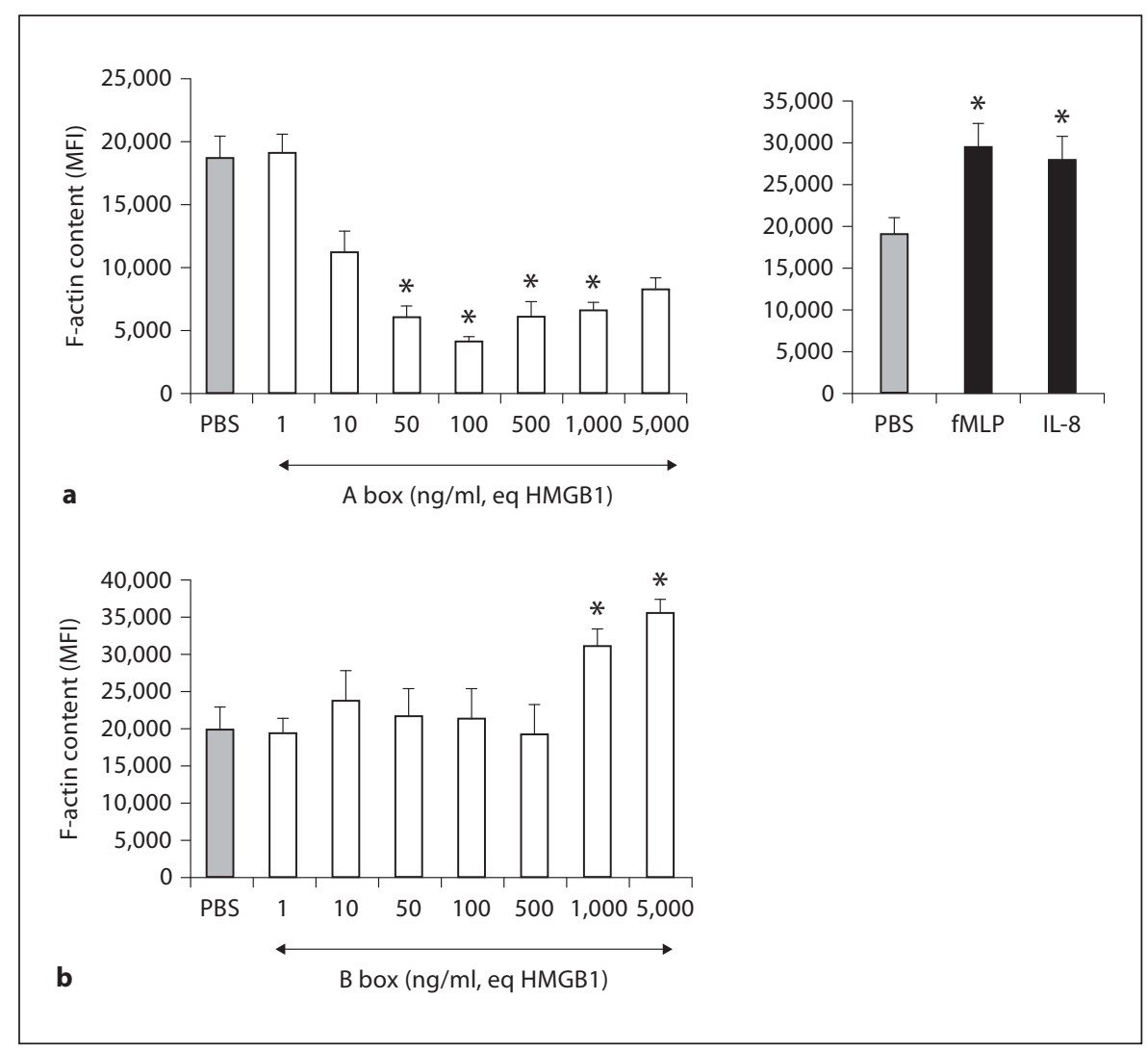

Fig. 4. Effect of A and B box on actin cytoskeleton modifications. a, $\mathbf{b}$ Effect of A and B box on actin polymerization. Whole-blood samples were incubated with PBS, A box (1-5,000 ng/ml, HMGB1 equivalent) (a) or B box (1-5,000 ng/ml, HMGB1 equivalent) (b) for $1 \mathrm{~h}$. IL-8 $(25 \mathrm{ng} / \mathrm{ml})$ and fMLP $\left(10^{-7} \mathrm{M}\right)$ were added for $2 \mathrm{~min}$ as positive controls. F-actin content was measured from the binding of Alexa Fluor 488-phalloidin, as described in Materials and
Methods. Nonspecific binding, determined with an excess of unlabeled phalloidin, was not modified by A box, B box, fMLP or IL-8. The results are expressed in mean fluorescence intensity. Values are means $\pm \operatorname{SEM}(\mathrm{n}=3)$. ${ }^{*}$ Significantly different from samples incubated with PBS (a, b), fMLP $(\mathbf{c}, \mathbf{e})$ or IL-8 (d, f) $(\mathrm{p}<$ $0.05)$. ulations have been linked to PMN activation, leading to L-selectin enzymatic shedding and translocation of intracellular stocks of CD11b to the cell membrane.

We have previously reported that, in whole blood, a given stimulus gives rise to minimal ROS production by PMN that have not been preactivated ('primed') [16]. We therefore studied the effect of HMGB1 on the oxidative burst after PMN priming. As shown in figure $5 \mathrm{~g}$ and $\mathrm{h}$, neither A nor B box modulated ROS production in response to fMLP.

\section{The HMGB1-Induced Increase in PMN Migration Is}

Related to IL-8 Synthesis

Preincubation of whole-blood samples for $30 \mathrm{~min}$ with cycloheximide $(10 \mu \mathrm{g} / \mathrm{ml})$ suppressed the HMGB1-induced increase in PMN migration but had no effect on the HMGB1-induced decrease in PMN migration observed at lower concentrations (fig. 6a). In addition, incubation of whole-blood samples with HMGB1 $(1,000$ and $5,000 \mathrm{ng} / \mathrm{ml}$ ) for $3 \mathrm{~h}$ significantly increased IL- 8 production as compared to PBS (fig. $6 \mathrm{~b}$ ), while TNF- $\alpha, \mathrm{IL}-1 \beta$ and IL- 6 remained undetectable (fig. 6c). In keeping with previous data [7], preincubation of whole-blood samples with the A box for 15 min suppressed HMGB1-induced IL-8 production (fig. 6b). HMGB1 induced significantly less IL-8 production than LPS, with levels never exceeding $6 \mathrm{ng} / \mathrm{ml}$ after $3 \mathrm{~h}$ of incubation (fig. 6b). However, IL-8 was found to have a chemotactic effect at concentrations as low as $2.5 \mathrm{ng} / \mathrm{ml}$ (fig. 6d). The HMGB1-induced increase in PMN migration was totally reversed by preincubation of whole-blood samples with an anti-IL-8 antibody (fig. 6e), while an irrelevant antibody of the same 


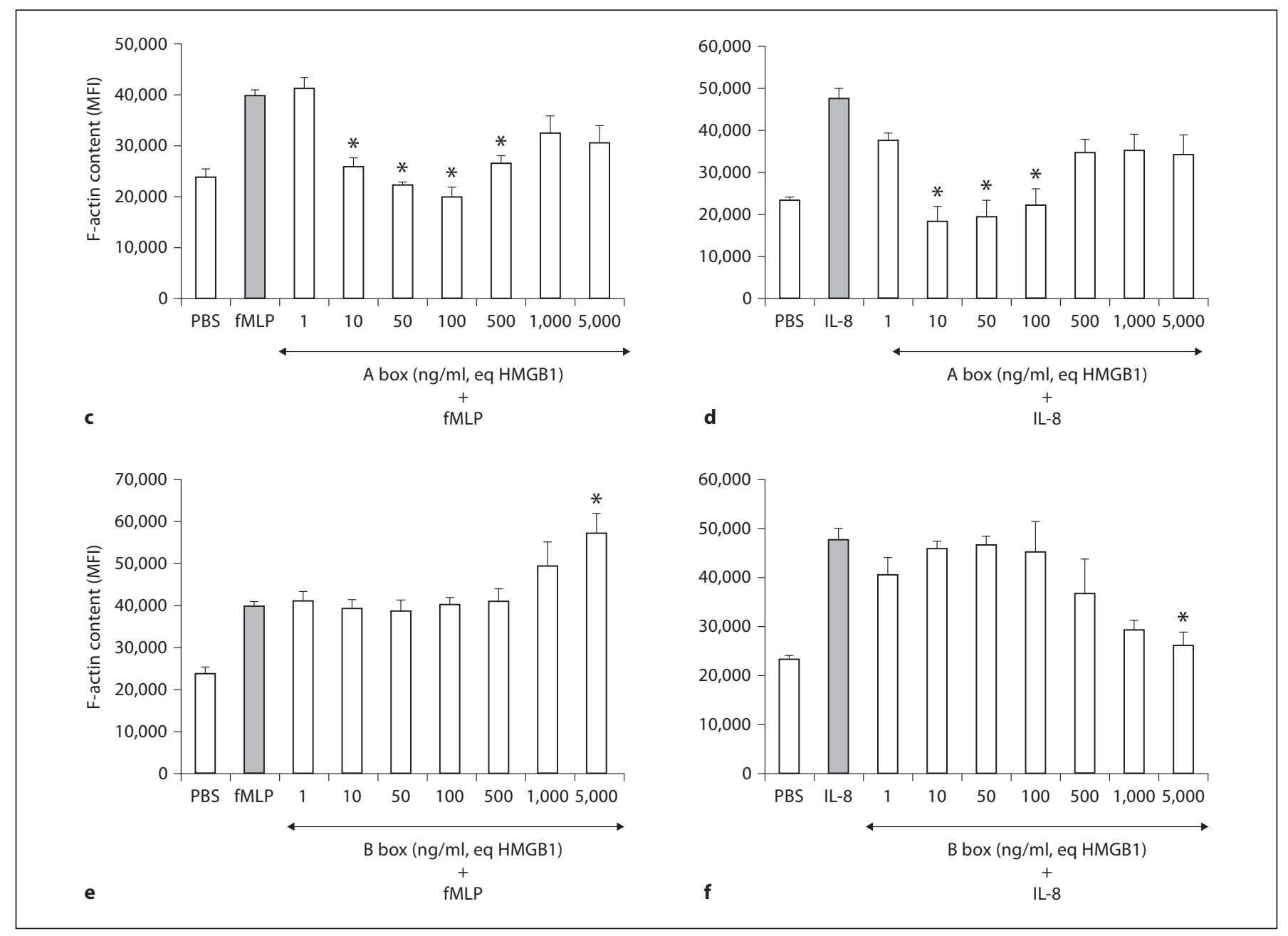

Fig. 4. Effect of $\mathrm{A}$ and $\mathrm{B}$ box on actin cytoskeleton modifications. c-f Effect of A and B box on chemoattractant-induced actin polymerization. After preincubation with PBS, A box (1-5,000 ng/ ml, HMGB1 equivalent) (c, d) or B box (1-5,000 ng/ml, HMGB1 equivalent) (e, f) for $1 \mathrm{~h}$, samples were then incubated for $2 \mathrm{~min}$ with PBS, fMLP $\left(10^{-6} \mathrm{M}\right)(\mathbf{c}, \mathbf{e})$ or IL-8 $(25 \mathrm{ng} / \mathrm{ml})(\mathbf{d}, \mathbf{f}) . \mathrm{F}$ actin content was measured as described above. Values are means \pm $\operatorname{SEM}(\mathrm{n}=3)$. * Significantly different from samples incubated with $\operatorname{PBS}(\mathbf{a}, \mathbf{b}), \operatorname{fMLP}(\mathbf{c}, \mathbf{e})$ or IL-8 (d, f) $(\mathrm{p}<0.05)$. isotype had no effect. These findings suggested that HMGB1-induced IL-8 production might be involved in the chemotactic effect of HMGB1 on PMN.

\section{Transduction Pathways Involved in HMGB1-Induced Modulation of PMN Migration}

We examined the possible involvement of RAGE, TLR2 and TLR4 in the differential modulation of PMN migration by HMGB1. As shown in figure 7a, the inhibitory effect of HMGB1 $100 \mathrm{ng} / \mathrm{ml}$ on PMN migration was strongly countered by cell pretreatment with antiRAGE, while the stimulatory effect of HMGB1 5,000 ng/ $\mathrm{ml}$ was significantly countered by pretreatment with an-
ti-RAGE, anti-TLR2 or anti-TLR4. We also analyzed the effect of advanced glycation end products (AGEs), reported to interact with RAGE, on PMN migration. We observed a decrease in PMN random migration in the presence of AGEs at 50 and $100 \mathrm{ng} / \mathrm{ml}$, while higher concentrations did not have a significant chemotactic effect (fig. 7b). Together, these results suggest that the decrease in PMN migration observed with low concentrations of HMGB1 is mediated by RAGE receptors, while supplementary engagement of TLR2 and TLR4 may be required for the enhancement of PMN chemotaxis observed at higher HMGB1 concentrations. In keeping with previous data [20], preincubation of whole-blood 


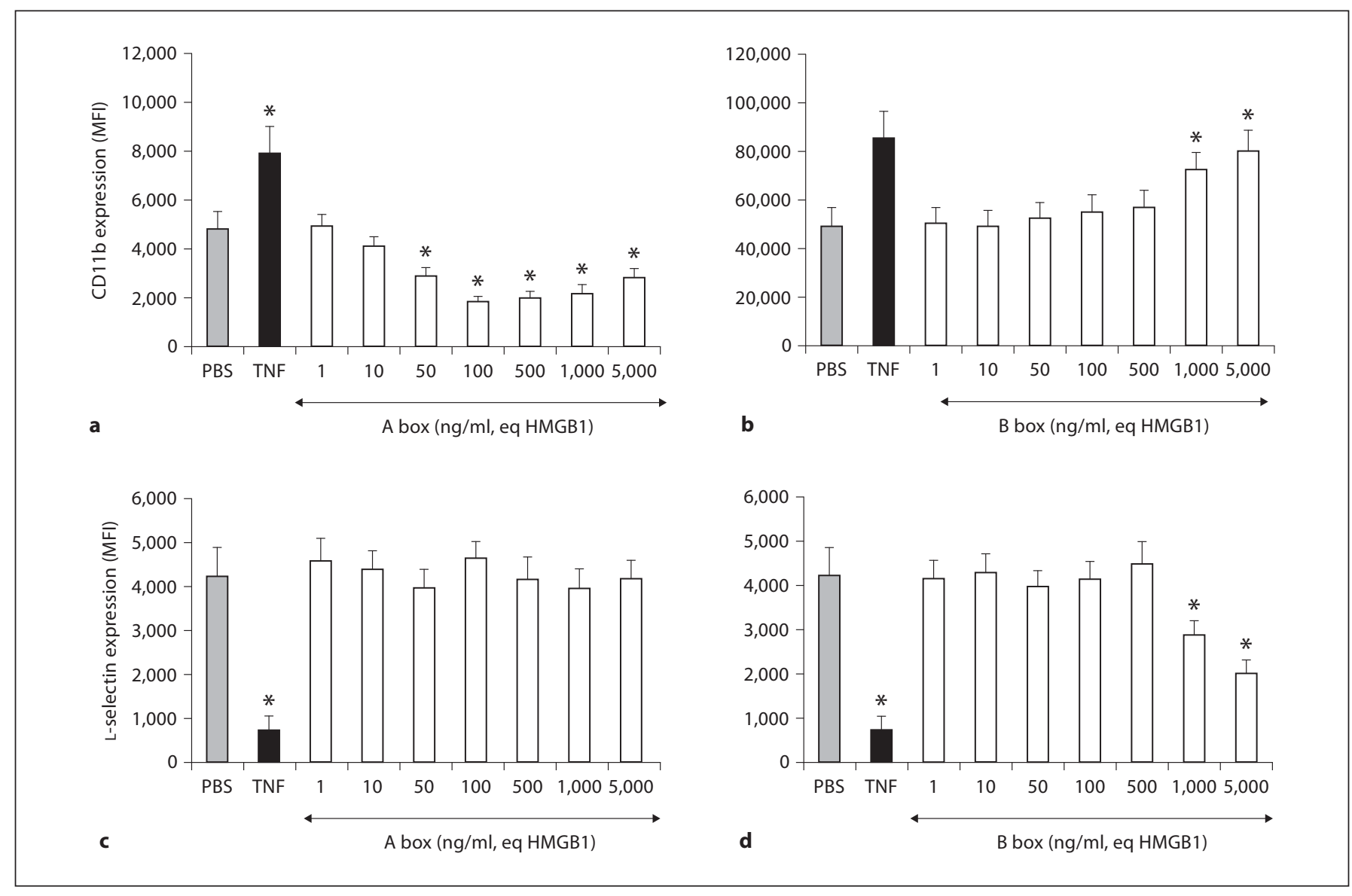

Fig. 5. Effect of A and B box on PMN adhesion molecule expression and oxidative burst. a-d Effect of $\mathrm{A}$ and $\mathrm{B}$ box on adhesion molecule expression. Whole-blood samples were incubated at $37^{\circ} \mathrm{C}$ for $1 \mathrm{~h}$ with PBS, A box (1-5,000 ng/ml, HMGB1 equivalent) (a, c), B box (1-5,000 ng/ml, HMGB1 equivalent) (b, d) or TNF- $\alpha$ $(100 \mathrm{U} / \mathrm{ml}$, used as a positive control). Samples were then stained with PE-anti-CD11b (a, b) and purified anti-L-selectin (c, d) antibodies at $4^{\circ} \mathrm{C}$ for $30 \mathrm{~min}$. The results are expressed as mean fluorescence intensity $(M F I)$. Values are means $\pm \operatorname{SEM}(n=3)$. ${ }^{*}$ Significantly different from samples incubated with PBS (a-d), fMLP $(\mathbf{e}, \mathbf{g}, \mathbf{h})$ or IL-8 (f) $(\mathrm{p}<0.05)$. samples with anti-RAGE, anti-TLR2 or anti-TLR4 significantly reduced HMGB1-induced IL-8 production (fig. 6f).

We then investigated the possible participation of various kinases in A box-induced inhibition of PMN migration, by using pharmacological inhibitors of PI3-K (wortmannin), as well as ERK1/2 inhibitor (PD98059) and p38MAPK inhibitor (SB206580). As shown in figure 7c, inhibition of p38MAPK and PI3-K suppressed the chemotactic effect of HMGB1 5,000 ng/ml and accentuated the inhibitory effect of HMGB1 $100 \mathrm{ng} / \mathrm{ml}$. Interestingly, HMGB1-induced inhibition of PMN migration was totally reversed in the presence of the ERK1/2 inhibitor PD98059. Moreover, incubation of whole blood with low concentrations of A box increased the phospho-ERK1/2 content (fig. 7d) and decreased the phospho-p38MAPK content (fig. 7e). Pretreatment with the ERK1/2 inhibitor reversed the A box-induced decrease in PMN phosphop38MAPK content (fig. 7f).

\section{Discussion}

Neutrophils are the first cells to be recruited to sites of infection in response to a variety of inflammatory stimuli, and they protect the host by engulfing, killing and digesting invading infectious agents. However, in case of excessive or misdirected responses, PMN may have detrimental effects that contribute to many inflammatory disorders [21]. Fine regulation of PMN recruitment is 


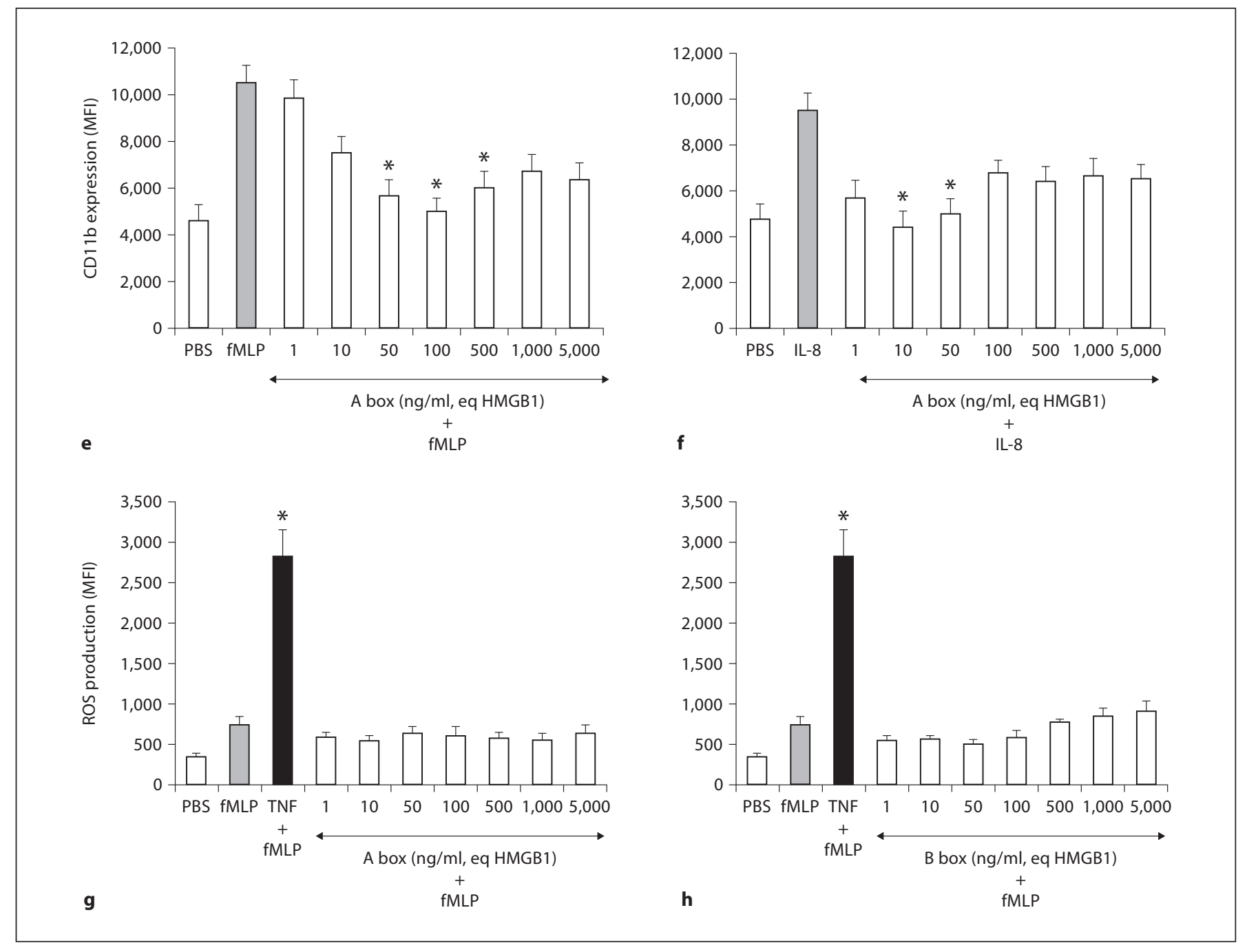

Fig. 5. Effect of A and B box on PMN adhesion molecule expression and oxidative burst. e, $\mathbf{f}$ Effect of A box on chemoattractantinduced CD11b upregulation. After preincubation with PBS or A box (1-5,000 ng/ml, HMGB1 equivalent) for $15 \mathrm{~min}$ and then with PBS, fMLP $\left(10^{-6} \mathrm{M}\right)(\mathbf{e})$ or IL-8 $(25 \mathrm{ng} / \mathrm{ml})(\mathbf{f})$ for respectively 5 or $45 \mathrm{~min}, \mathrm{CD} 11 \mathrm{~b}$ expression was measured as described above. The results are expressed as mean fluorescence intensity (MFI). Values are means $\pm \operatorname{SEM}(\mathbf{n}=3) . \mathbf{g}, \mathbf{h}$ Effect of A and B box on PMN oxidative burst. Whole-blood samples were pretreated with HE for $15 \mathrm{~min}$ at $37^{\circ} \mathrm{C}$ and then incubated for $1 \mathrm{~h}$ with PBS, A box (1-5,000 ng/ml, HMGB1 equivalent) (g), B box (1-5,000 ng/ml, HMGB1 equivalent) (h) or TNF- $\alpha$ (100 U/ml), followed by fMLP stimulation $\left(10^{-6} \mathrm{M}, 5 \mathrm{~min}\right)$. The results are expressed as mean fluorescence intensity (MFI). Values are means $\pm \operatorname{SEM}(n=3)$. * Significantly different from samples incubated with PBS (a-d), fMLP $(\mathbf{e}, \mathbf{g}, \mathbf{h})$ or IL-8 (f) $(\mathrm{p}<0.05)$.

moattractants. HMGB1 release by dying cells at inflammatory sites, including PMN [23], could trigger a different 'braking circuit' that limits neutrophil recruitment and thereby reduces collateral tissue damage during physiological inflammatory responses. Thus, our study identifies HMGB1 as one of few molecules, alongside lactoferrin, lipoxins, netrin-1 and annexin-1, that negatively regulate neutrophil migration [24-27]. This modulation could be attributed to the truncated A box of the protein, 
Fig. 6. The HMGB1-induced increase in PMN migration is related to IL-8 synthesis by blood cells. a Effect of cycloheximide on HMGB1-induced changes in PMN migration. Cycloheximide $(10 \mu \mathrm{g} / \mathrm{ml})$ or PBS was added to whole-blood samples placed in the upper wells. The lower well of each chamber received $600 \mu \mathrm{l}$ of PBS-HSA (1\%), HMGB1 100 ng/ml or HMGB1 5,000 ng/ $\mathrm{ml}$. The chambers were incubated for 1 or $3 \mathrm{~h}$ at $37^{\circ} \mathrm{C}$ and the results are expressed either as the percentage inhibition or as the percentage increase, depending on the HMGB1 concentration (100 ng/ml or $5,000 \mathrm{ng} / \mathrm{ml}$, respectively), as described in the legend of figure $1 \mathrm{~b}$. Values are means \pm SEM $(n=3)$. * Significantly different from sample incubated with PBS ( $\mathrm{p}<$ 0.05). b, c Effect of HMGB1 on IL-8, TNF, IL-1 and IL- 6 production by whole-blood cells. Whole-blood samples were incubated for $3 \mathrm{~h}$ with PBS, HMGB1 (1-5,000 ng/ $\mathrm{ml})$ or LPS (10 $\mathrm{ng} / \mathrm{ml}$, used as a positive control). Cytokine production was measured with a human inflammatory cytokine CBA kit. In some experiments, wholeblood samples were treated with A box (100 ng/ml, HMGB1 equivalent) in addition to HMGB1. Values are means \pm SEM $(\mathrm{n}=3) .{ }^{*}$ Significantly different from sample incubated with PBS $(\mathrm{p}<0.05)$.
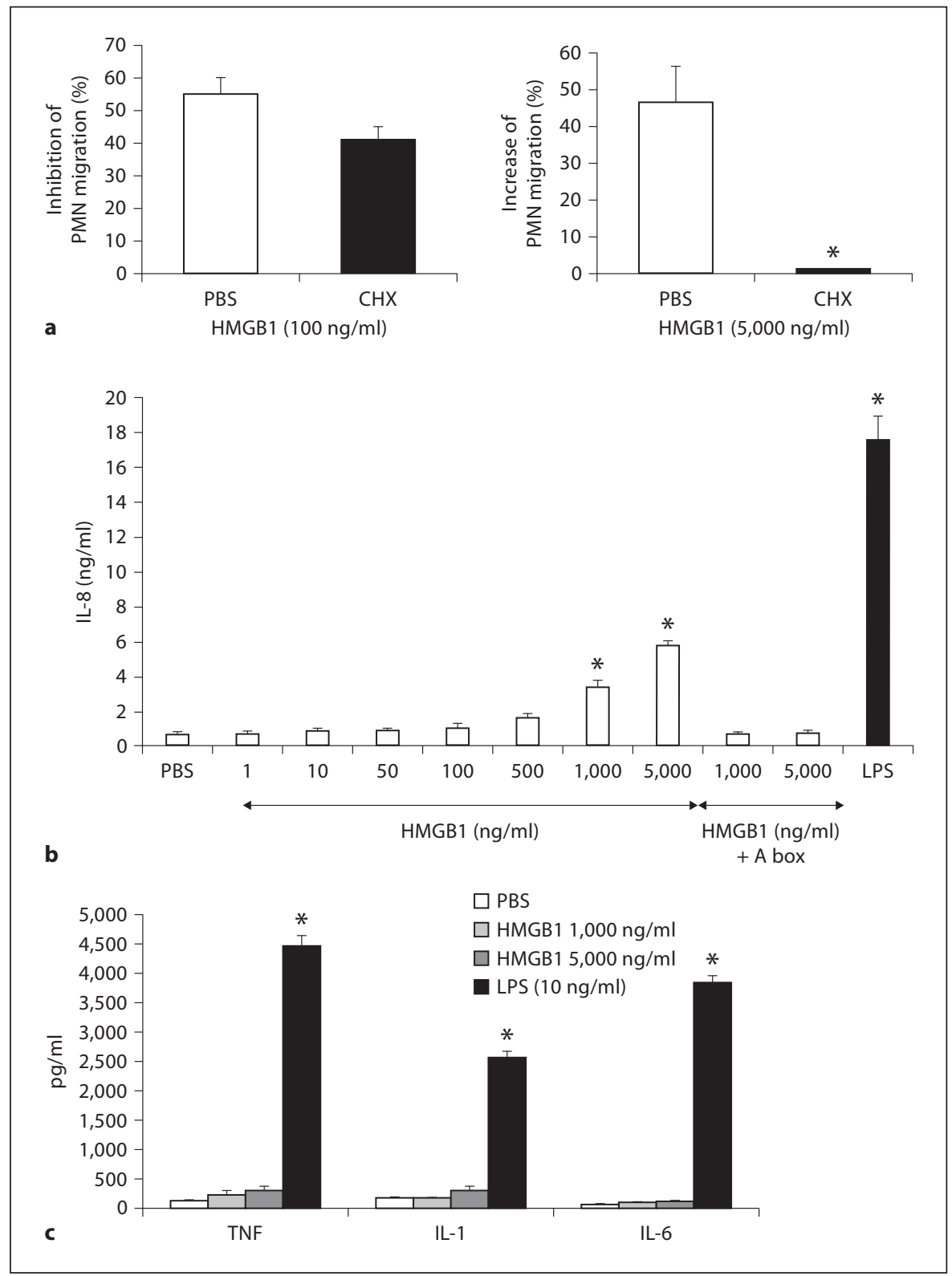

which inhibits PMN migration as well as CD11b expression and actin polymerization.

In contrast, PMN chemotaxis was enhanced by elevated HMGB1 concentrations (5,000 ng/ml). High HMGB1 concentrations have been found in tissues during chronic inflammatory disorders such as rheumatoid arthritis and cystis fibrosis $[28,29]$ and might thus amplify PMN recruitment to the inflammatory site and lead to bystander tissue damage. In keeping with the results of structure-function studies [7] demonstrating that the active cytokine domain of HMGB1 is located in the DNA-binding B box, we found that the B box, when used alone, increased PMN migration and modulated $\mathrm{CD} 1 \mathrm{lb}$ and L-selectin expression at the PMN surface. The observed chemotactic effect of HMGB1 involved blood-cell production of IL-8, which exerts its chemoattractant function even at concentrations as low as $2.5 \mathrm{ng} /$ $\mathrm{ml}$. In contrast, the stimulatory effect of IL-8 on ROS production and PMN survival (online supplementary figure 1, www.karger.com/doi/10.1159/000328798) in whole-blood conditions appears at higher concentrations (above $25 \mathrm{ng} / \mathrm{ml}$ ), explaining, at least in part, why 
Fig. 6. The HMGB1-induced increase in PMN migration is related to IL-8 synthesis by blood cells. $\mathbf{d}$ Effect of IL-8 on PMN migration. The lower well of each chamber received $600 \mu \mathrm{l}$ of PBS-HSA (1\%) or IL-8 $(0.1-25 \mathrm{ng} / \mathrm{ml})$. The chambers were incubated for $1 \mathrm{~h}$ at $37^{\circ} \mathrm{C}$. The results are expressed as the migration rate number of PMN in the lower well after migration/ number of PMN applied to the upper well) $\times 100$. Values are means $\pm \operatorname{SEM}(n=3)$. * Significantly different from sample incubated with PBS-HSA ( $\mathrm{p}<0.05)$. e Effect of an anti-IL-8 antibody on the HMGB1-induced increase in PMN migration. Before being applied to the upper chamber, whole-blood samples were pretreated at $37^{\circ} \mathrm{C}$ for 15 min with PBS or an anti-human IL-8 antibody. The lower well of each chamber received $600 \mu \mathrm{l}$ of PBS-HSA (1\%) or HMGB1 (100-5,000 ng/ml). The chambers were incubated for $1 \mathrm{~h}$ at $37^{\circ} \mathrm{C}$. The results are expressed as the migration rate (number of PMN in the lower well after migration/number of PMN applied to the upper well before migration) $\times 100$. Values are means \pm SEM $(n=3) .{ }^{*}$ Significantly different from sample incubated with PBS instead of anti-IL-8 antibody $(p<0.05)$. f Involvement of RAGE, TLR2 and TLR4 in HMGB1-induced IL- 8 production. Whole-blood samples were pretreated for 30 min with blocking antiRAGE antibody $(10 \mu \mathrm{g} / \mathrm{ml})$, blocking antiTLR2 antibody $(10 \mu \mathrm{g} / \mathrm{ml})$, or blocking anti-TLR4 antibody $(10 \mu \mathrm{g} / \mathrm{ml})$ and then incubated for $3 \mathrm{~h}$ with PBS or HMGB1 $(5,000 \mathrm{ng} / \mathrm{ml})$. IL- 8 production was measured as described above. Values are means $\pm \operatorname{SEM}(\mathrm{n}=3) .{ }^{*}$ Significantly different from samples incubated with HMGB1 alone $(\mathrm{p}<0.05)$.
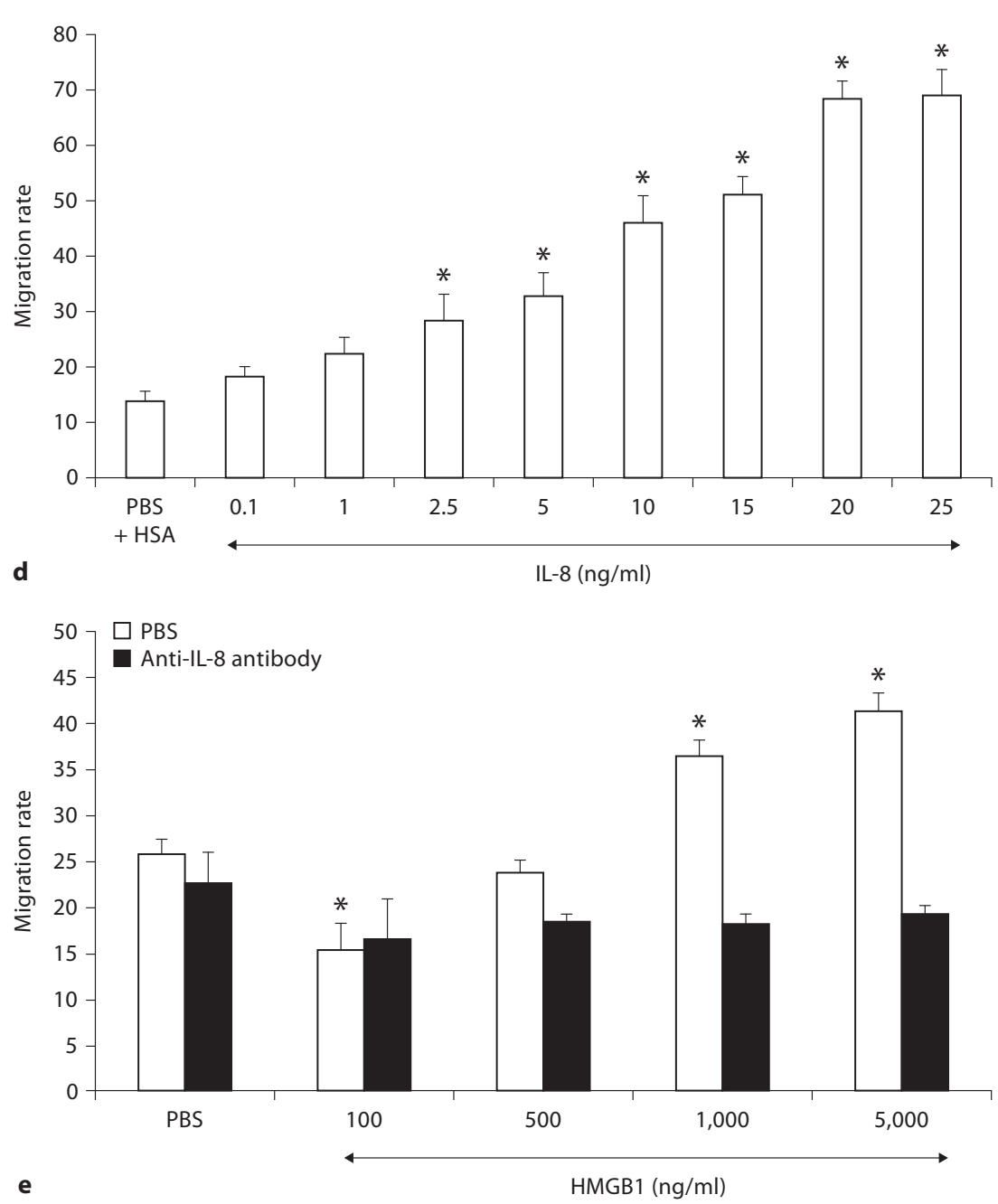

e

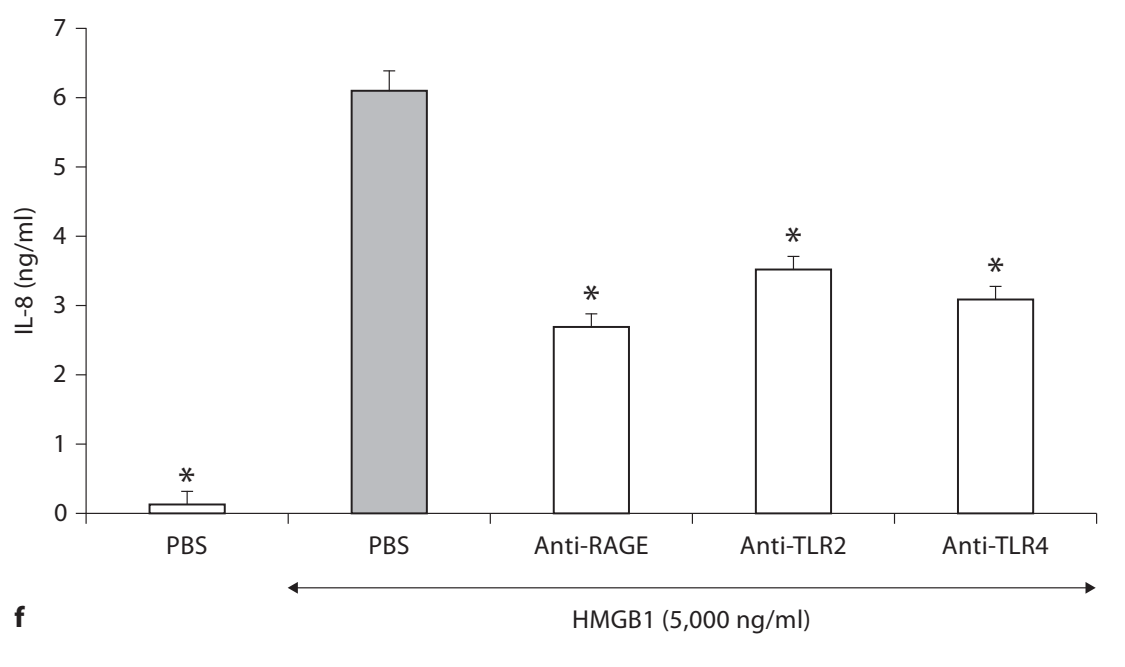


Fig. 7. Transduction pathways involved in HMGB1 modulation of PMN migration. a, b Involvement of RAGE, TLR2 and TLR4 in HMGB1-induced modulation of PMN migration. a Before being applied to the upper chambers, whole-blood samples were pretreated at room temperature for 30 min with blocking anti-RAGE antibody (10 $\mu \mathrm{g} / \mathrm{ml})$, blocking anti-TLR2 antibody $(10 \mu \mathrm{g} / \mathrm{ml})$, or blocking anti-TLR4 antibody $(10 \mu \mathrm{g} / \mathrm{ml})$. The lower well of each chamber received $600 \mu \mathrm{l}$ of PBS-HSA or HMGB1 (100 ng/ml or 5,000 ng/ml). The chambers were incubated for $1 \mathrm{~h}$ (HMGB1 $100 \mathrm{ng} / \mathrm{ml}$ ) or $3 \mathrm{~h}$ (HMGB1 5,000 ng/ml) at $37^{\circ} \mathrm{C}$. The results are expressed as the percentage inhibition or percentage increase, depending on the HMGB1 concentration (100 or $5,000 \mathrm{ng} / \mathrm{ml}$, respectively) as described in the legend of figure $1 \mathrm{~b}$. Values are means $\pm \operatorname{SEM}(n=3)$. * Significantly different from sample incubated with PBS instead antibody $(\mathrm{p}<0.05)$. b Concentration-dependent effect of AGEs on PMN migration. The lower well of each chamber received $600 \mu \mathrm{l}$ of PBS-HSA (1\%) or AGEs $(1-5,000 \mathrm{ng} / \mathrm{ml})$. The chambers were incubated for $3 \mathrm{~h}$ at $37^{\circ} \mathrm{C}$. The results are expressed as the migration rate. Values are means $\pm \operatorname{SEM}(n=10)$. * Significantly different from sample incubated with PBSHSA ( $p<0.05)$. c Effect of kinase inhibitors on the HMGB1-induced decrease in PMN migration. Before being applied to the upper chambers, whole-blood samples were pretreated at $37^{\circ} \mathrm{C}$ for $15 \mathrm{~min}$ with PBS, PI3K inhibitor (wortmannin 2,500 nM), ERK1/2 inhibitor (PD980569 $50 \mu \mathrm{M}$ ), or p38MAPK inhibitor (SB203580 $25 \mu \mathrm{M}$ ). The lower well of each chamber received $600 \mu \mathrm{l}$ of PBS-HSA (1\%) or HMGB1 (100 or $5,000 \mathrm{ng} / \mathrm{ml}$ ). The chambers were incubated for $1 \mathrm{~h}$ at $37^{\circ} \mathrm{C}$. The results are expressed as the percentage inhibition, as described in the legend of fig. 1b. Values are means $\pm \operatorname{SEM}(\mathrm{n}=3)$.

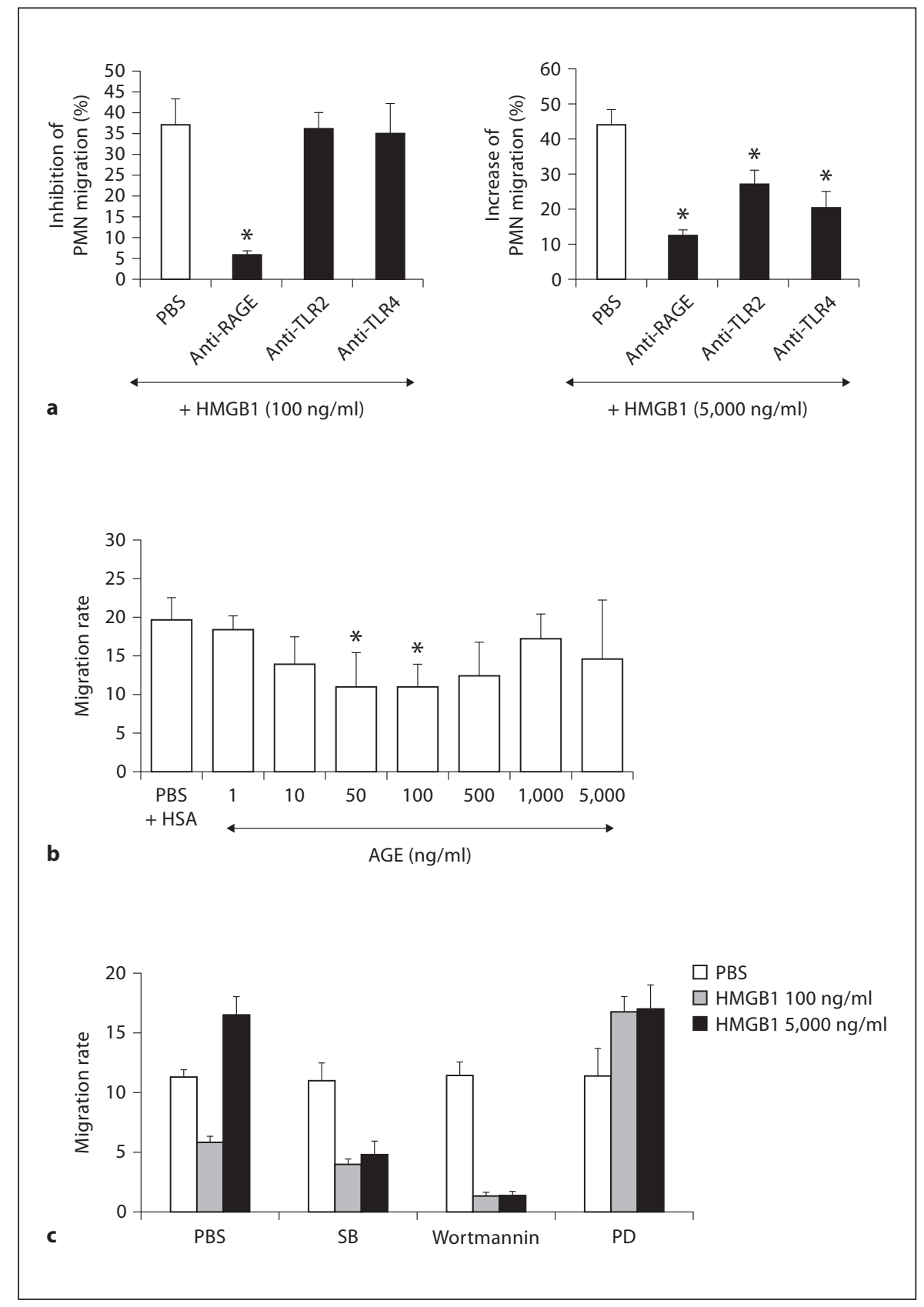

the B box did not stimulate these functions. In addition, the chemoattractant effect of HMGB1 was countered by pretreatment with anti-TLR2 and anti-TLR4 antibodies, in keeping with the involvement of TLR2 and TLR4 in HMGB1-induced IL-8 production. Finally, the synergistic effect of fMLP and HMGB1 $(5,000 \mathrm{ng} / \mathrm{ml})$ may be related to cross talk between TLR4 and chemokine receptors, leading to a marked increase in chemokinedriven migration [31].
The intracellular signaling pathways mediating the biological effects of extracellular HMGB1 are poorly documented. In particular, although RAGE has been identified as the receptor for HMGB1, we do not know how RAGE transfers signals to the effectors required for cytoskeleton remodeling and cell migration to the transcriptional machinery. HMGB1 binding to RAGE leads to the activation of multiple signaling molecules, including ERK1/2, p38MAPK, the small GTPases rac and Cdc42, 
Fig. 7. Transduction pathways involved in HMGB1 modulation of PMN migration. d Effect of HMGB1 on intracellular ERK1/2 phosphorylation. Whole-blood samples were preincubated at $37^{\circ} \mathrm{C}$ with PBS or A box (1-5,000 ng/ml, HMGB1 equivalent) for $10 \mathrm{~min}$. Phospho-ERK1/2 content was measured by flow cytometry on methanol-permeabilized cells as described in Materials and Methods. The results are expressed in MFI. Values obtained with an irrelevant antibody of the same isotype were subtracted. Values are means $\pm \operatorname{SEM}(n=3)$. ${ }^{*}$ Significantly different from sample incubated with PBS $(p<0.05)$. e, $\mathbf{f}$ Effect of ERK1/2 inhibitor on HMGB1-induced p38MAPK phosphorylation. Whole-blood samples were pretreated at $37^{\circ} \mathrm{C}$ for $10 \mathrm{~min}$ with $\mathrm{PBS}(\mathbf{e})$ or ERK1/2 inhibitor (PD98056950 $\mu \mathrm{M})(\mathbf{f})$ and then with PBS or A box (1-5,000 ng/ $\mathrm{ml}$, HMGB1 equivalent) for $10 \mathrm{~min}$. Phospho-p38MAPK content was measured by flow cytometry on methanol-permeabilized cells as described in Materials and Methods. The results are expressed in MFI. Values obtained with an irrelevant antibody of the same isotype were subtracted. Values are means $\pm \operatorname{SEM}(n=3)$. * Significantly different from sample incubated with PBS $(\mathrm{p}<0.05)$.
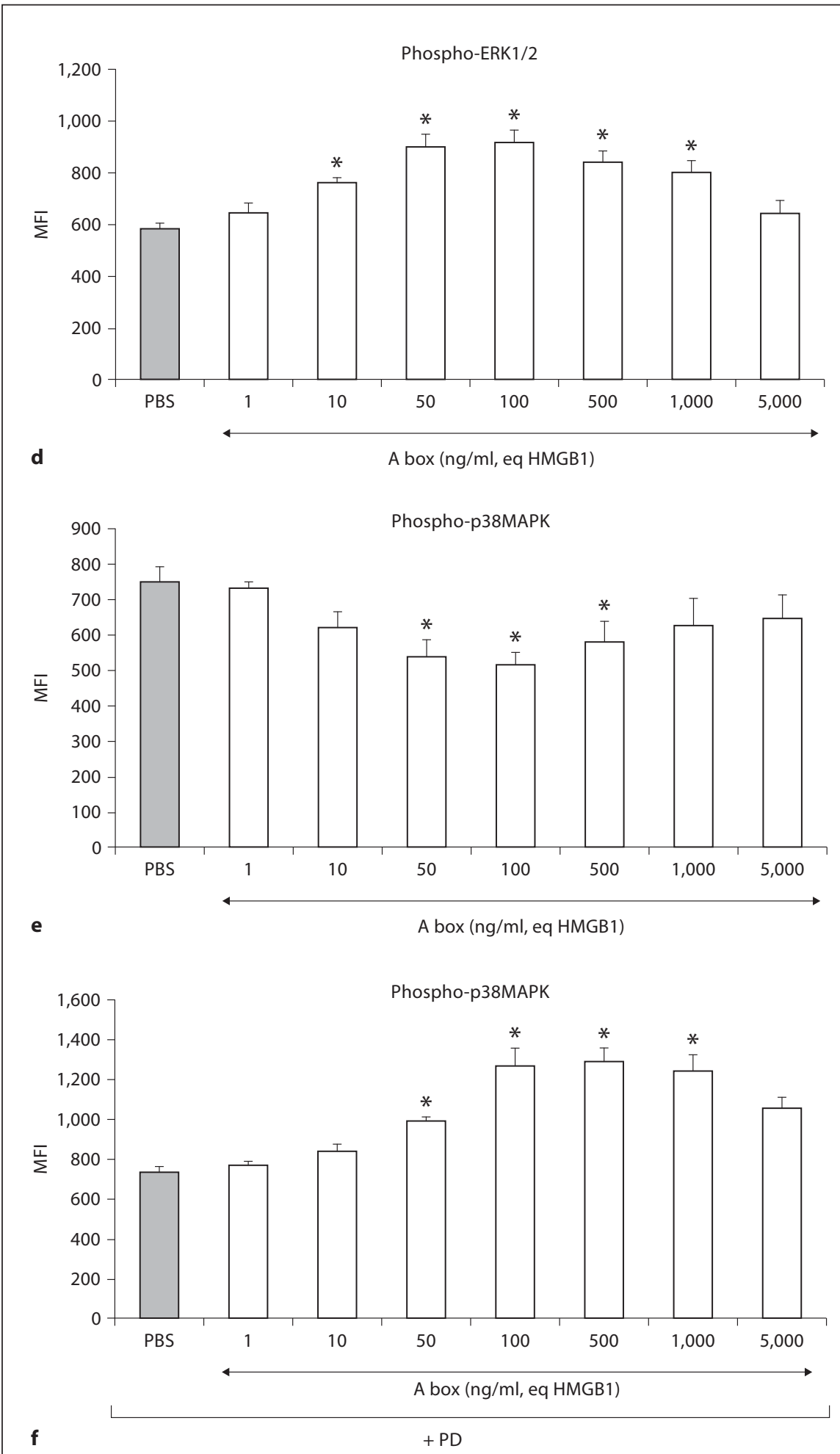
and NF- $\kappa \mathrm{B}$ [3]. The signaling pathway between RAGE and downstream signal transducers is not fully characterized. We observed that ERK1/2 inhibition reversed the HMGB1-induced decrease in baseline PMN migration as well as in PMN chemotaxis towards IL-8 and fMLP. Moreover, the truncated A box, shown to inhibit PMN migration, increased the phospho-ERK1/2 content (fig. 7d) and decreased the phospho-p38MAPK content (fig. 7e), while pretreatment with the ERK1/2 inhibitor reversed the A box-induced decrease in PMN phosphop38MAPK content. A potential mechanism for HMGB1 inhibition of chemotaxis may involve $G$ protein-coupled receptor (GPCR) desensitization. Several studies have demonstrated a prominent role of GPCR kinase (GRK)2 in the phosphorylation and internalization of chemokine receptors in PMN, leading to desensitization [33]. Interestingly, GRK2 has been reported to act as an inactivator of p38MAPK, thereby inhibiting p38MAPK-mediated cellular processes [34]. Furthermore, GPCR internalization has been closely linked to increased ERK1/2 phosphorylation $[35,36]$. Further studies are needed to determine the possible role of HMGB1-induced ERK1/2 activation in GRK2 upregulation, p38MAPK inactivation, and GPCR phosphorylation and desensitization.

HMGB1 inhibitors have been shown to reduce inflammation in dozens of preclinical animal studies, using antiHMGB1 antibodies, the anti-inflammatory agent ethyl pyruvate (which reduces nuclear export of HMGB1) and the HMGB1 A box. The A box, originally found to participate in maintaining nucleosome structure and regulating gene transcription [38], was subsequently shown to be a spe- cific HMGB1 antagonist. A box administration inhibits HMGB1 activity and is beneficial in models of inflammatory disorders such as endotoxemia and sepsis [7], pancreatitis [39], arthritis [28], stroke [40], and ischemia-reperfusion injury [41], although the molecular bases of this antiinflammatory activity are currently unclear. It has been reported that the A Box binds to RAGE, TLR2 and TLR4 with no intrinsic pro-inflammatory activity $[7,42]$. In contrast, the A box attenuates HMGB1-induced pro-inflammatory cytokine release by macrophage-like RAW 264.7 cells [7]. In accordance with these data, we found that the A box strongly inhibited IL-8 production by blood cells, and also the increase in PMN migration induced by high HMGB1 concentrations. In addition, we demonstrate, for the first time, that the A box also has an anti-inflammatory action, decreasing both $\mathrm{PMN}$ random migration and PMN chemotaxis. Gong et al. [43], in a murine model of LPS-induced acute lung injury, found that the A box caused a significant reduction in PMN numbers in bronchoalveolar lavage fluid. Although this reduction may be related to downregulation of LPS-induced chemokine and pro-inflammatory cytokine production, it may also involve a direct effect on RAGE signaling pathways, in turn affecting the actin cytoskeleton and PMN migration.

In conclusion, we show that HMGB1/RAGE interaction downregulates PMN migration. Our results also indicate that the A box may be the ideal HMGB1 antagonist for use in inflammatory disorders associated with excessive HMGB1 production, by limiting PMN recruitment and thereby avoiding bystander tissue damage.

\section{References}

1 Babior BM: Oxidants from phagocytes: agents of defense and destruction. Blood 1984;64:959-966.

$>2$ Bokoch GM: Chemoattractant signaling and leukocyte activation. Blood 1995;86:16491660.

$>3$ Bianchi ME, Manfredi AA: High mobility group box 1 (HMGB1) protein at the crossroads between native and adaptive immunity. Immunol Rev 2007;220:35-46.

4 Sha Y, Zmijewski J, Xu Z, Abraham E: HMGB1 develops enhanced proinflammatory activity by binding to cytokines. J Immunol 2008;180:2531-2537.

$\checkmark 5$ Tian J, Avalos AM, Mao SY, Chen B, Senthil K, Wu H, Parroche P, Drabic S, Golenbock D, Sirois C, Hua J, An LL, Audoly L, La Rosa G, Bierhaus A, Naworth P, Marshak-Rothstein A, Crow MK, Fitzgerald KA, Latz E, Peter A, Kiener PA, Coyle AJ: Toll-like receptor 9-de- pendent activation by DNA-containing immune complexes is mediated by HMGB1 and RAGE. Nat Immunol 2007;8:487-496.

$\checkmark 6$ Youn JH, Oh YJ, Kim ES, Choi JE, Shin JS: High mobility group box 1 protein binding to lipopolysaccharide facilitates transfer of lipopolysaccharide to CD14 and enhances lipopolysaccharide-mediated TNF- $\alpha$ production in human monocytes. J Immunol 2008;180:5067-5074.

77 Yang H, Ochani M, Li J, Qiang X, Tanovic M, Harris HE, Susarla SM, Ulloa L, Wang H, DiRaimo R, Czura CJ, Roth J, Warren HS, Fink MP, Fenton MJ, Andersson U, Tracey $\mathrm{KJ}$ : Reversing established sepsis with antagonists of endogenous high-mobility group box 1. Proc Natl Acad Sci USA 2004;101: 296-301.

-8 Orlova VV, Choi EY, Xie C, Chavakis E, Bierhaus A, Ihanus E, Ballantyne CM, Gahm- berg CG, Bianchi ME, Nawroth PP, Chavakis T: A novel pathway of HMGB1-mediated inflammatory cell recruitment that requires Mac-1-integrin. EMBO J 2007;26:1129-1139.

$\checkmark 9$ Kuijpers TW, Tool ATJ, Van der Schoot CE, Ginsel LA, Onderwater JJM, Roos D, Verhoeven AJ: Membrane surface antigen expression on neutrophils: a reappraisal of the use of surface markers for neutrophil activation. Blood 1991;78:1105-1111.

10 Jaouen S, de Koning L, Gaillard C, Muselikova-Polanska E, Stros M, Strauss F: Determinants of specific binding of HMGB1 protein to hemicatenated DNA loops. J Mol Biol 2005;353:822-837.

11 Thierry S, Gozlan J, Jaulmes A, Boniface R, Nasreddine N, Strauss F, Maréchal V: Highmobility group box 1 protein induces HIV-1 expression from persistently infected cells. AIDS 2007;21:283-292. 
$\checkmark 12$ Gaillard C, Borde C, Gozlan J, Maréchal V, Strauss F: A high-sensitivity method for detection and measurement of HMGB1 protein concentration by high-affinity binding to DNA hemicatenanes. PLoS ONE 2008; 3:e2855.

13 Palumbo R, De Marchis F, Pusterla T, Conti A, Alessio M, Bianchi ME: Src family kinases are necessary for cell migration induced by extracellular HMGB1. J Leukoc Biol 2009;86: 617-623.

-14 Elbim C, Monceaux V, Mueller YM, Lewis MG, François S, Diop O, Akarid K, Hurtrel B, Gougerot-Pocidalo MA, Levy Y, Katsikis PD, Estaquier J: Early divergence in neutrophil apoptosis between pathogenic and nonpathogenic SIV infections of non-human primates. J Immunol 2008;181:8613-8623.

15 François S, El Benna J, Dang PMC, Pedruzzi E, Gougerot-Pocidalo MA, Elbim C: Inhibition of neutrophil apoptosis by Toll-like receptor agonists in whole blood: involvement of the phosphoinositide 3-kinase/Akt and NF- $\mathrm{BB}$ signaling pathways leading to increased levels of Mcl-1, A1 and phosphorylated Bad. J Immunol 2005;174:3633-3642.

-16 Elbim C, Chollet-Martin S, Bailly S, Hakim J, Gougerot-Pocidalo MA: Priming of polymorphonuclear neutrophils (PMN) by tumor necrosis factor $\alpha$ in whole blood: identification of two PMN subpopulations in response to formyl-peptides. Blood 1993;82 633-640.

17 Wlodkowic D, Skommer J, Pelkonen J: Towards an understanding of apoptosis detection by SYTO dyes. Cytometry A 2007;71A: 61-72.

18 Wymann MP, Kernen P, Bengtsson T, Andersson T, Baggiolini M, Deranleau DA: Corresponding oscillations in neutrophil shape and filamentous actin content. J Biol Chem 1990;265:619-622.

-19 Powner DJ, Pettitt TR, Anderson R, Nash GB, Wakelam MJ: Stable adhesion and migration of human neutrophils requires phospholipase D-mediated activation of the integrin CD11b/CD18. Mol Immunol 2007;44: 3211-3221.

-20 Park JS, Gamboni-Robertson F, He Q, Svetkauskaite D, Kim JY, Strassheim D, Sohn JW, Yamada S, Maruyama I, Banerjee A, Ishizaka A, Abraham E: High mobility group box 1 protein interacts with multiple Toll-like receptors. Am J Physiol Cell Physiol 2006; 290:C917-C924.

21 Weiss SJ: Tissue destruction by neutrophils. N Engl J Med 1989;320:365-376.

-22 Touré F, Zahm JM, Garnotel R, Lambert E, Bonnet N, Schmidt AM, Vitry F, Chanard J, Gillery P, Rieu P: Receptor for advanced glycation end-products (RAGE) modulates neutrophil adhesion and migration on glycoxidated extracellular matrix. Biochem J 2008;416:255-261.
3 Rovere-Querini P, Capobianco A, Scaffidi P, Valentinis B, Catalanotti F, Giazzon M, Dumitriu IE, Müller S, Iannacone M, Traversari C, Bianchi ME, Manfredi AA: HMGB1 is an endogenous immune adjuvant released by necrotic cells. EMBO Rep 2004;5:825-830.

24 Takata S, Matsubara M, Allen PG, Janmey PA, Serhan CN, Brady HR: Remodeling of neutrophil phospholipids with 15(S)-hydroxyeicosatetraenoic acid inhibits leukotriene B4-induced neutrophil migration across endothelium. J Clin Invest 1994;93:499-508.

25 Ly NP, Komatsuzaki K, Fraser IP, Tseng AA, Prodhan P, Moore KJ, Kinane TB: Netrin-1 inhibits leukocyte migration in vitro and in vivo. Proc Natl Acad Sci USA 2005;102: 14729-14734.

26 Hayhoe RP, Kamal AM, Solito E, Flower RJ, Cooper D, Perretti M: Annexin 1 and its bioactive peptide inhibit neutrophil-endothelium interactions under flow: indication of distinct receptor involvement. Blood 2006; 107:2123-2130.

27 Bournazou I, Pound JD, Duffin R, Bournazos S, Melville LA, Brown SB, Rossi AG, Gregory CD: Apoptotic human cells inhibit migration of granulocytes via release of lactoferrin. J Clin Invest 2009;119:20-32.

-28 Kokkola R, Li J, Sundberg E, Aveberger AC, Pamblad K, Yang H, Tracey KJ, Andersson U, Harris HE: Successful treatment of collageninduced arthritis in mice and rats by targeting extracellular high mobility group box chromosomal protein 1 activity. Arthritis Rheum 2003;48:2052-2058.

29 Rowe SM, Jackson PL, Liu G, Hardison M, Livraghi A, Solomon GM, McQuaid DB, Noerager BD, Gaggar A, Clancy JP, O’Neal W, Sorscher EJ, Abraham E, Blalock JE: Potential role of high-mobility group box 1 in cystic fibrosis airway disease. Am J Respir Crit Care Med 2008;178:822-831.

30 Elbim C, Bailly S, Chollet-Martin S, Hakim J, Gougerot-Pocidalo MA: Differential priming effects of proinflammatory cytokines on human neutrophil oxidative burst in response to bacterial $\mathrm{N}$-formyl peptides. Infection and Immunity 1994;62:2195-2201.

31 Fan J, Malik AB: Toll-like receptor-4 (TLR4) signaling augments chemokine-induced neutrophil migration by modulating cell surface expression of chemokine receptors. Nat Med 2003;9:315-321.

32 Knall C, Worthen GS, Johnson GL: Interleukin 8-stimulated phosphatidylinositol-3kinase activity regulates the migration of human neutrophils independent of extracellular signal-regulated kinase and p38 mitogen-activated protein kinases. Proc Natl Acad Sci USA 1997;94:3052-3057.
3 Oppermann M, Mack M, Proudfoot AEI, Olbrich H: Differential effects of CC chemokine receptor 5 (CCR5) phosphorylation and identification of phosphorylation sites on the CCR5 carboxy terminus. J Biol Chem 1999;274:8875-8885.

- 34 Peregrin S, Jurado-Pueyo M, Campos PM, Sanz-Moreno V, Ruiz-Gomez A, Crespo P, Mayor F, Murga C: Phosphorylation of p38 by GRK2 at the docking groove unveils a novel mechanism for inactivating p38MAPK. Curr Biol 2006; 16:2042-2047.

- 35 Tatsukawa T, Chimura T, Miyakawa H, Yamaguchi K: Involvement of basal protein kinase $\mathrm{C}$ and extracellular signal-regulated kinase $1 / 2$ activities in constitutive internalization of AMPA receptors in cerebral Purkinje cells. J Neurosci 2006;26:4820-4825.

36 Wolff M, Kredel WM, Haasen D, Wiedenmann J, Nienhaus GU, Kistler B, Oswald F, Heilker R: High content screening of CXCR2-dependent signalling pathways. Comb Chem High Throughput Screen 2010;13:3-15.

37 Chen GY, Tang J, Zheng P, Liu Y: CD24 and Siglec-10 selectively repress tissue damageinduced immune responses. CD24 and Siglec-10 selectively repress tissue damage-induced immune responses. Science 2009;323: 1722-1725.

38 Landsman D, Bustin MA: Signature for the HMG-1 box DNA-binding proteins. Bioassays 1993;15:539-546.

39 Yuan H, Jin X, Sun J, Li F, Feng Q, Zhang C, Cao Y, Wang Y: Protective effect of HMGB1 A box on organ injury of acute pancreatitis in mice. Pancreas 2009;38:143-148.

40 Muhammad S, Barakat W, Stroyanov S, Murikinati S, Yang H, Tracey KJ, Bendszus M, Rossetti G, Nawroth PP, Bierhaus A, Schwaninger M: The HMGB1 receptor RAGE mediates ischemic brain damage. J Neurosci 2008;28:12023-12120.

- 41 Andrassy M, Volz HC, Igwe JC, Funke B, Eichberger SN, Kaya S, Buss S, Autschbach F, Pleger ST, Lukic IK, Bea F, Hardt SE, Humpert PM, Bianchi ME, Mairbäurl H, Nawroth PP, Remppis A, Katus HA, Bierhaus A: High-mobility group box-1 in ischemia-reperfusion injury of the heart. Circulation 2008;117:3216-3226.

-42 Huang Y, Yin H, Han J, Huang B, Xu J, Zheng F, Tan Z, Fang M, Rui L, Chen D, Wang S, Zheng X, Wang CY, Gong F: Extracellular HMGB1 functions as an innate immune-mediator implicated in murine cardiac allograft acute rejection. Am J Transplant 2007;4: 799-808.

-43 Gong Q, Xu JF, Yin H, Liu SF, Duan LH, Bian ZL: Protective effect of antagonist of highmobility group box 1 on lipopolysaccharideinduced acute lung injury in mice. Scand J Immunol 2009;69:29-35. 